\title{
USTAVNOPRAVNA ZAŠTITA PRAVA OSOBA S DUŠEVNIM SMETNJAMA ${ }^{1}$
}

\author{
Doc. dr. sc. Dalida Rittossa*
}

UDK: 342.7-056.37(497.5) (094.9)

Ur.: 28. studenoga 2017.

Pr.: 4. prosinca 2017.

Izvorni znanstveni rad

\begin{abstract}
Sažetak
U zadnjih nekoliko godina u stručnoj i široj javnosti mogu se čuti učestale rasprave u kojima se upozorava na prava i položaj osoba s duševnim smetnjama. Jedan od razloga koji su potaknuli zanimljive dijaloge zasigurno je $i$ stupanje na snagu novoga Zakona o zaštiti osoba s duševnim smetnjama početkom 2015. godine. Zakonodavne akcije rezultirale su učvršćivanjem prava i posebnog položaja psihijatrijskih pacijenata na zakonodavnoj razini, no ostalo je otvoreno pitanje, priznaju li se uistinu prava i slobode ove posebne kategorije građana i u praksi. Budući da je ustavnopravna zaštita krunska zaštita sloboda i prava svih građana, istražena je cjelokupna sudska praksa Ustavnog suda Republike Hrvatske u razdoblju od 1992. do 1. studenog 2017. godine. Prikupljen je uzorak od 31 odluke i rješenja u kojima je sud raspravljao o ustavnosti ograničenja priznatih prava osoba s duševnim smetnjama. Detaljnom analizom ovog uzorka izdvojeni su ustavnopravni standardi o zaštiti prava građana s psihičkim problemima i uspoređeni s već odavno prihvaćenim ustavnopravnim rješenjima u judikaturi Europskog suda za ljudska prava i Vrhovnog suda SAD-a. U završnim razmatranjima predlažu se smjernice za poboljšanje ustavnopravne zaštite osoba s duševnim smetnjama u Republici Hrvatskoj u kontekstu poticanja sudskog aktivizma.
\end{abstract}

Ključne riječi: osobe s duševnim smetnjama, ustavnopravna zaštita sloboda i prava psihijatrijskih pacijenata, Ustavni sud Republike Hrvatske, sudski aktivizam.

* Dr. sc. Dalida Rittossa, docentica Pravnog fakulteta Sveučilišta u Rijeci; dalida@pravri.hr

1 Ovaj rad je sufinancirala Hrvatska zaklada za znanost projektom IP-11-2013-2287 „Legal Status and Real Position of People with Mental Difficulties - Interdisciplinary Approach and European Perspectives“ i Sveučilište u Rijeci potporama znanstvenim istraživanjima 13.08.1.3.02 „Interdisciplinarni pristup u istraživanju statusa osoba s duševnim smetnjama kroz prizmu konvencijskog prava“. 


\section{ZAŠTO GOVORITI O USTAVNOPRAVNOJ ZAŠTITI OSOBA S DUŠEVNIM SMETNJAMA?}

Davne 1819. godine u presudi McCulloch v. Maryland, John Marshall, predsjednik Vrhovnog suda Sjedinjenih Američkih Država, izrekao je tvrdnju kako su tvorci Ustava sročili ovaj temeljni dokument s namjerom da ga se primjenjuje $u$ stoljećima koja će tek doći i u različitim krizama u odnosima i poslovima čovjeka. ${ }^{2}$ Ustavnopravni stručnjaci i teoretičari i danas podupiru tezu kako Ustav kao temeljni pravni akt ne smije biti podložan učestalim izmjenama i dopunama i kako ga se treba izuzeti iz postupka hiper normizacije. Ustav treba sadržavati temeljna pravna načela kako bi se njegovim pravilnim tumačenjem uredile konkretne zakonske i podzakonske norme i donijela većini prihvatljiva društvena pravila. ${ }^{3}$ No, osim inzistiranja na nepromjenjivosti Ustava, u riječima suca Marshalla može se iščitati već mnogo puta potvrđena zakonitost da se upravo u postupcima pred najvišim državnim sudištima, tumačenjem ustavnih odredbi, nastoje iznaći rješenja za društveno osjetljive odnose. Drugim riječima, mnoga društvena i politička pitanja prerast će u ustavnopravna pitanja i dobiti svoj epilog u postupcima pred ustavnim sudovima, kada se za to ostvare uvjeti u društvu i kada kulturološke, političke i društvene sile dovedu do toga da takvo jedno pitanje dosegne svoje žarište za čije je rješavanje neminovna ustavnopravna

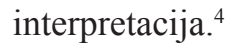

Prema podatcima Svjetske zdravstvene organizacije čini se da je duševno zdravlje modernog čovjeka opasno narušeno. Zadnje studije upozoravaju da duševni poremećaji čine znatan udio u ukupnom obolijevanju svjetske populacije i da su vodeći razlog zbog kojeg osobe provode veliki dio svoga života s invaliditetom. ${ }^{5} \mathrm{Na}$ temelju globalnih zdravstvenih statistika pretpostavlja se da danas u svijetu tri stotine milijuna ljudi pati od depresije i šezdeset milijuna od bipolarnog poremećaja. Visoke brojke

2 McCulloch v. Maryland, 17 U.S. 316 (1819), objavljeno u: Chemerinsky, E.: Constitutional Law, Aspen Law \& Business, Gaithersburg, New York, 2001., str. 96.

3 O razlozima veće trajnosti i otežanom mijenjanju odredbi Ustava u odnosu na zakonske norme vidi u: Smerdel, B.: Ustavno uređenje europske Hrvatske, Narodne novine, Zagreb, 2013., str. 74.-75.; O ustavnim odredbama kojima je svrha rješavanja temeljnih odnosa u društvu i promjenama Ustava vidi u: Bačić, A.: Ustavne promjene i dileme konstitucionalizma, Zbornik radova Pravnog fakulteta u Splitu, vol. 46, br. 4, 2009., str. 649.-666.; O prirodi ustavnih odredbi kao izjavama vrijednosti, manifestaciji moći, koordinacijskim mehanizmima i svojevrsnom ugovoru kao glavnim razlozima za podupiranje teze zašto Ustav ne treba često mijenjati vidi u: Galligan, D. J. i Versteeg, M.: Theoretical Perspectives on the Social and Political Foundations of Constitutions, objavljeno u: Galligan, D. J. i Versteeg, M. (ur.): Social and Political Foundations of Constitutions, Cambridge University Press, Cambridge, 2015., str. 3.-48.

4 U novije vrijeme ustavnopravna teorija učinila je novi pomak u tumačenju svrhe odredbi Ustava. Autori se i dalje slažu kako je primaran cilj normi temeljnoga pravnog akta postaviti institute koji će reflektirati i osigurati racionalna rješenja za društvene probleme, no isto tako ističu da se te iste norme izgrađuju u emocijama pokrenutim postupcima koji odražavaju trenutne emocije javnosti, odnosno osnovne moralne osjećaje. Istaknute tvrdnje dijelom su teorijskih postavki o „ustavnom sentimentalizmu“. Sajó, A.: Emotions in Constitutional Institutions, Emotion Review, vol. 8, br. 1, 2016., str. 44.-49.

5 World Health Organisation, Calouste Gulbenkian Foundation: Improving Access to and Appropriate Use of Medicines for Mental Disorders, Geneva, 2017., str. 10. 
vezuju se i uz demenciju i shizofreniju. Prema prikupljenim podatcima o prevalenciji bolesti na svjetskoj razini vjeruje se da četrdeset i sedam milijuna i petsto tisuća osoba boluje od demencije i dvadeset i jedan milijun od shizofrenije. ${ }^{6}$ Alarmantni pokazatelji o učestalosti duševnih smetnji pretočeni u konkretne ekonomske posljedice u svjetskim razmjerima pokazuju da će u razdoblju od 2011. do 2030. godine nastati kumulativni gospodarski gubitak u iznosu od 16,3 bilijuna američkih dolara što će se dramatično odraziti na produktivnost i kvalitetu života oboljelih osoba i gurnuti ih na granicu siromaštva. ${ }^{7}$

Regionalni statistički pokazatelji prate naznačeni globalni trend. Nacionalni institut za mentalno zdravlje zabilježio je da je 43,4 milijuna punoljetnih građana patilo od duševnih smetnji u Sjedinjenim Američkim Državama u 2015. godini. ${ }^{8}$ Brojke nisu bile nimalo ohrabrujuće niti ranijih godina pa je tako zaključeno na temelju dvaju kompleksnih nacionalnih studija provedenih početkom osamdesetih i devedesetih godina (The Epidemiologic Catchment Area i The National Comorbidity Survey), da se u godini dana u prosjeku dijagnosticira duševna smetnja jednom od pet Amerikanaca, odnosno populaciji od oko 44 milijuna osoba starijih od 18 godina. ${ }^{9}$ Zabrinjavajući podatci o pobolijevanju od duševnih smetnji zabilježeni su i u europskoj regiji. Prema službenim statistikama Eurostata u 2014. godini 3,5 milijuna Europljana otpušteno je iz psihijatrijskih ustanova po završetku bolničkog liječenja zbog duševnog poremećaja ili poremećaja u ponašanju. Prosječan broj dana koji su psihijatrijski pacijenti proveli $\mathrm{u}$ europskim bolnicama u toj godini prešao je vrtoglavu brojku od 82 milijuna. I u Europi je depresija jedan od glavnih dijagnostičkih pokazatelja narušenoga duševnog zdravlja građana pa tako statistike pokazuju da je $5 \%$ Europljana i $9 \%$ Europljanki patilo od depresije u 2014. godini. ${ }^{10}$

Službene statistike Hrvatskog zavoda za javno zdravstvo upozoravaju da se faktografska slika obolijevanja hrvatskih građana u mnogome ne razlikuje od globalnih i regionalnih pokazatelja. Primjerice, u 2015. godini kod 474887 pacijenata u primarnoj zaštiti dijagnosticiran je duševni poremećaj ili poremećaj u ponašanju što u konačnici znači da je svaki deveti hrvatski građanin obolio od neke duševne smetnje. Usporedbom podataka o oboljelima u 2005. godini kada su duševne smetnje utvrđene kod 379582 osoba, proizlazi da je broj pacijenata s duševnim smetnjama u samo deset godina porastao za više od $20 \% .^{11}$

6 World Health Organisation: Mental disorders, Fact sheet - April 2017, objavljeno na: <http:// www.who.int/mediacentre/factsheets/fs396/en/>, zadnji put posjećeno 1. studenog 2017.

7 Bloom, D. E. i dr.: The Global Economic Burden of Noncommunicable Diseases, World Economic Forum, Harvard School of Public Health, Geneva, 2011., str. 5.

8 Center for Behavioral Health Statistics and Quality: Key Substance Use and Mental Health Indicators in the United States: Results from the 2015 National Survey on Drug Use and Health, Rockville, 2016., str. 27.

9 U.S. Department of Health and Human Services: Mental Health: A Report of the Surgeon General, Rockville, 1999., str. 15., 46.

10 Eurostat: Mental Health and Related Issues Statistics, objavljeno na: <http://ec.europa.eu/ eurostat/statistics-explained/index.php/Mental_health_and_related_issues_statistics>, zadnji put posjećeno 1. studenog 2017.

11 Hrvatski zavod za javno zdravstvo, Hrvatski zdravstveno-statistički ljetopis za 2005. i 2015. godinu, Zagreb, 2006., 2016., str. 122. i 92. 
Zabilježeni vrtoglavi skok dio je općeg fenomena koji je odavno poprimio globalne razmjere, a koji jasno pokazuje da su duševne smetnje visoko prisutne u modernom društvu i da se slobodno može govoriti o krizi mentalnog zdravlja. Stoga ne čudi da su se u zadnjih nekoliko desetljeća intenzivirale ideje o pravnoj zaštiti osoba s duševnim smetnjama. ${ }^{12}$ Progresivna mišljenja koja su ukazivana na opravdanost i nužnost stvaranja posebnoga zakonodavnog okvira za zaštitu ove posebne grupe pacijenata mogla su se čuti u stručnim i znanstvenim krugovima, ali i u svakodnevnom diskursu koji je posebno poticao sektor neprofitnih organizacija u Republici Hrvatskoj. ${ }^{13}$ Slijedom pozitivnog razvoja politika zaštite mentalnog zdravlja, krajem 1997. godine donesen je Zakon o zaštiti osoba s duševnim smetnjama (ZZODS/97), prvi zasebni zakon koji je na sveobuhvatan način uredio položaj i prava onih koji pate od duševne smetnje i osigurao zaštitne mehanizme u slučaju povrede tih prava. ${ }^{14} \mathrm{U}$ turbulentnom razdoblju koje je uslijedilo zbog izostanka konsenzusa stručnjaka o prihvatljivosti usvojenih zakonodavnih rješenja, ${ }^{15}$ ZZODS/97 je nekoliko

12 Zakon o mentalnom zdravlju Ujedinjenog Kraljevstva iz 1959. godine jedan je od prvih cjelovitih zakona kojim se sustavno uređuje prisilna hospitalizacija osoba s duševnim smetnjama. I nakon gotovo šezdeset godina, u ovoj je zemlji na snazi poseban zakon s identičnim nazivom iz 2007. godine. Osim što sadrži odredbe o identičnim pravnim institutima, Zakon o mentalnom zdravlju iz 2007. godine donosi mnogobrojna progresivna rješenja poput postavljanja „nezavisnog zagovornika mentalnog zdravlja“, posebno ovlaštene osobe za pružanje pomoći psihijatrijskim pacijentima. Danas zasebne zakonodavne akte kojima se reguliraju položaj i prava psihijatrijskih bolesnika imaju mnogobrojne zemlje, pa tako Belgija (Zakon o zaštiti osoba s problemima vezanim uz duševno zdravlje iz 1990.), Danska (Pročišćeni zakon o mjerama prisile u psihijatriji iz 2006.), Francuska (Zakon br. 2011-803 o pravima i zaštiti osoba koje su podvrgnute psihijatrijskoj skrbi te o modalitetima te skrbi iz 2011.), Irska (Zakon o mentalnom zdravlju iz 2001.), Luksemburg (Zakon o hospitalizaciji osoba s problemima vezanim uz duševno zdravlje bez njihovog pristanka iz 2009.), Novi Zeland (Zakon o mentalnom zdravlju [o obveznoj procjeni i liječenju] iz 1992.) kao i pojedine pokrajine u Kanadi (Zakon o mentalnom zdravlju Ontarija i Alberte iz 1990., Zakon o mentalnom zdravlju Britanske Kolumbije iz 1996., Zakon o zaštiti pacijenata s duševnim smetnjama Quebeca iz 1997., Zakon br. 109. Nove Škotske iz 2004. itd.).

13 O povijesnom prikazu geneze nastanka pravne zaštite osoba s duševnim smetnjama u Republici Hrvatskoj i pravnoj praksi vidi u: Grozdanić, V.: Novi Zakon o zaštiti osoba s duševnim smetnjama - između zahtjeva konvencijskog prava i mogućnosti hrvatskog društva, objavljeno u: Grozdanić, V. (ur.): Komentar Zakona o zaštiti osoba s duševnim smetnjama s provedbenim propisima, međunarodnim dokumentima i presudama Europskog suda za ljudska prava, Pravni fakultet Sveučilišta u Rijeci, Rijeka, 2015., str. XIII.-XIX. Na polju praktične zaštite građana s duševnim smetnjama posebno su se afirmirale Sjaj, udruga za društvenu afirmaciju osoba s psiho-socijalnim teškoćama osnovana 1998. godine te Let, udruga za unapređenje kvalitete življenja koja je započela s radom 2002. godine.

14 Zakon o zaštiti osoba s duševnim smetnjama, NN 111/1997.

$15 \mathrm{O}$ (ne)opravdanom kriticizmu odredbi i nerazumijevanju duha ZZODS/97 te nepripremljenosti i nedovoljnoj educiranosti dijela psihijatara i pravnika za njegovu primjenu, kao i o krajnje birokratskom pristupu zaštiti prava osoba s duševnim smetnjama progovara Goreta u: Goreta, M.: Nekoliko napomena o potencijalnom unapređenju primjene ZZODS-a prema aktualno važećim rješenjima i nekoliko prijedloga za promjene rješenja koja su se u dosadašnjoj primjeni ZZODS-a pokazala nezadovoljavajućim (materijali od 8. siječnja 1999. god.), str. 10., citirano prema Škorić, M. i Srdoč, E.: Pravni položaj neubrojivih počinitelja protupravnih djela u Republici Hrvatskoj, Zbornik radova Pravnog fakulteta u Splitu, vol. 52, br. 4, 2015., str. 944. 
puta izmjenjen i dopunjen ${ }^{16}$ da bi ga se dana 1. siječnja 2015. godine u potpunosti zamijenilo novim Zakonom o zaštiti osoba s duševnim smetnjama (ZZODS/14) koji je i danas na snazi. ${ }^{17}$ I u potonjem Zakonu sadržane su posebne odredbe o pravima i pravnoj zaštiti psihijatrijskih pacijenata. U duhu postojećih konvencijskih rješenja i odavno razvijene prakse Europskog suda za ljudska prava (nadalje ESLJP), ${ }^{18}$ zakonodavac je na detaljan i precizan način u posebnim glavama uredio temeljna načela i prava osoba s duševnim smetnjama. ${ }^{19}$ Ovakvi zakonodavni postupci pokazuju da je unatoč neslaganjima oko konkretizacije pojedinih zakonodavnih rješenja u hrvatskom društvu postignut konsenzus oko potrebe da se na zakonodavnoj razini urede prava osoba s duševnim smetnjama, i posebno, da se svako zatvaranje psihijatrijskog bolesnika podvrgne sudskoj kontroli u postupku prisilne hospitalizacije. ${ }^{20}$

Slijedom iznesenog, čini se opravdanim zaključiti kako je pitanje prava psihijatrijskih pacijenata doseglo Marshallov stupanj društvene aktualizacije, odnosno onu točku žarišta kada konkretno društveno pitanje postaje ustavnopravno pitanje na koje trebaju pružiti odgovor najviša državna sudišta. Iz tog razloga s posebnom pažnjom istražit će se praksa Ustavnog suda Republike Hrvatske u kojoj je sud zauzeo stajalište o (ne)postojanju povrede nekog od u zakonu posebno zagarantiranog prava osobe s duševnom smetnjom. Analizom odluka izdvojit će se postignuti ustavnopravni standardi o zaštiti prava ove posebne kategorije građana. Uočeni standardi kritički će se usporediti s već odavno prihvaćenim načelima i razrađenim ustavnopravnim rješenjima u praksi ESLJP-a i Vrhovnog suda SAD-a. Na ovakav način nastojat će se pružiti konkretan zaključak o kakvoći ustavnopravne zaštite psihijatrijskih pacijenata u Republici Hrvatskoj i pružiti daljnje smjernice za njezin budući razvoj.

\section{ISTRAŽIVANJE PRAKSE USTAVNOG SUDA REPUBLIKE HRVATSKE}

\subsection{Osnovne odrednice provedenog istraživanja}

Kako bi se ustanovilo povodom kojih pravnih pitanja i koliko je često zatražena zaštita prava i položaja osoba $\mathrm{s}$ mentalnim poremećajima pred Ustavnim sudom Republike Hrvatske, provedeno je istraživanje cjelokupne prakse ovog sudišta od 1992. do 1. studenog 2017. godine objavljene na njegovim službenim stranicama. ${ }^{21}$ Detaljno

16 Zakon o izmjenama i dopunama Zakona o zaštiti osoba s duševnim smetnjama, NN 27/1998., 128/1999., 79/2002.

17 Zakon o zaštiti osoba s duševnim smetnjama, NN 76/2014.

18 O obvezujućim normativnim rješenjima relevantnih međunarodnih ugovora i najvažnijim odlukama ESLJP-a koje su utjecale na zakonodavca pri izradi ZZODS/14 vidi u: Prilozi, objavljeno u: Grozdanić, V. (ur.): Komentar Zakona..., op. cit., str. 319.-432.

19 Glava II. i III. ZZODS/14.

20 Grozdanić, V., Tripalo, D.: Novosti u Zakonu o zaštiti osoba s duševnim smetnjama, Hrvatski ljetopis za kazneno pravo i praksu, vol. 20, br. 2, 2013., str. 799.-800.

21 Praksa Ustavnog suda Republike Hrvatske prema datumu donošenja odluka, objavljeno na: $<$ https://www.usud.hr/hr/prema-datumu-donosenja-odluka $>$, zadnji put posjećeno 1. studenog 2017. 
je analizirano 10213 odluka i rješenja o različitim ustavnopravnim problemima od kojih se u promatranom razdoblju njih 31 odnosilo na pravni položaj i zaštitu prava psihijatrijskih pacijenata. Kako bi se osigurala validnost uzorka, prikupljene odluke i rješenja provjerene su i preuzete i iz Narodnih novina. U Grafikonu 1. dan je detaljan prikaz pitanja kojima se ovo sudište bavilo kao i broj odluka u kojima je ocjenjivana ustavnost zakonskih rješenja i njihove provedbe u praksi tijekom postupanja nadležnih tijela prema osobama s duševnim smetnjama.

\subsection{Učestalost odlučivanja i pojedina pravna pitanja}

Grafikon 1. Ustavnopravna pitanja o pravima osoba s duševnim smetnjama pred Ustavnim sudom Republike Hrvatske i broj odluka od 1992. do 1. studenog 2017. godine

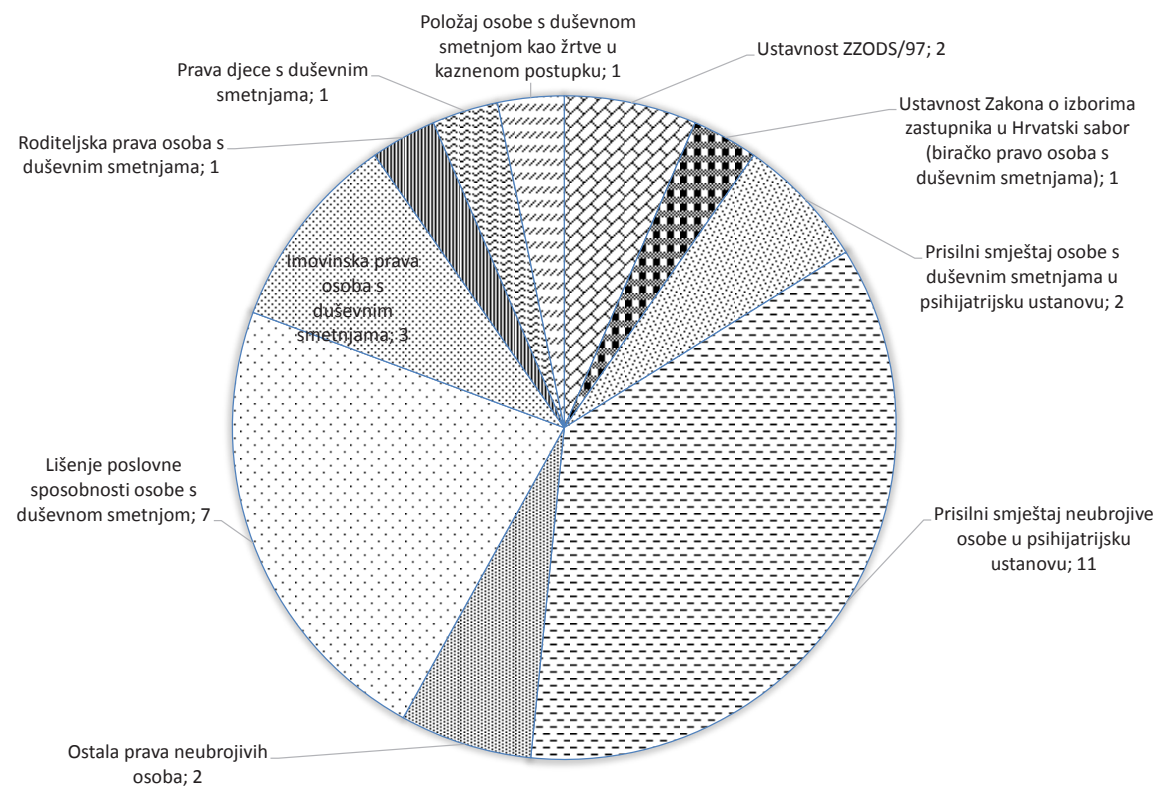

Iz predočenoga grafičkog prikaza moguće je zaključiti kako se u svojoj dosadašnjoj praksi Ustavni sud bavio pravnim položajem psihijatrijskih pacijenata i njihovim pravima iznimno rijetko. Predočeno u postotke, udio odluka i rješenja koje se odnose na ovu posebnu kategoriju pacijenata u ukupnom ustavnom sudovanju iznosi $0,3 \%$. Dosadašnja istraživanja pokazala su da slaba učestalost odlučivanja o pravima osoba s duševnim smetnjama našeg ustavnog sudišta ne predstavlja izdvojeni fenomen. Primjerice, analiza svih odluka Vrhovnog suda Norveške u razdoblju od 1904. do 2011. pokazala je da je najviši norveški sud u samo 29 slučajeva raspravljao o pravima psihijatrijskih pacijenata koja se ostvaruju tijekom njihovog boravka u psihijatrijskoj ustanovi i o ostalim građanskim pravima. ${ }^{22}$ Pretraživanje svih dostupnih odluka

22 Diseth, R. R.: Compulsory Mental Health Care in Norway: A Study of the Interface between the Law and Psychiatry, Division of Mental Health and Addiction, Institute of Clinical Medicine, Faculty of Medicine, University of Oslo, Oslo, 2013., str. 49.-51. 
Vrhovnog suda SAD-a donesenih nakon 1793. godine u bazi Westlaw i objavljenih na stranicama Instituta za pravne informacije Pravnog fakulteta Sveučilišta Cornell, pokazalo je da su suci raspravljali o predmetima osoba s duševnim smetnjama u 35 zasebna slučaja. ${ }^{23}$

Razlozi kojima bi se mogao objasniti ovako mali broj odluka najviših sudišta zasigurno su mnogobrojni i kontekstualno povezani s povijesnim okolnostima razvoja ustavnog sudovanja, zaštite temeljnih ljudskih prava i psihijatrije kao znanstvene discipline. Sve do trenutka dok se u pravnoj teoriji i praksi nisu usvojila stajališta o neupitnoj vrijednosti osobne slobode svakog pojedinca i prihvatili zaključci da je i prisilna hospitalizacija psihijatrijskih pacijenata oblik ograničenja te iste slobode, pravna zaštita na najvišim sudskim instancama bila je fragmentarna ili je u potpunosti izostala. Stoga ne čudi da je prvi put Vrhovni sud SAD-a odlučivao o ustavnosti prisilnog smještaja psihijatrijskog bolesnika u slučaju Minnesota ex rel. Pearson v. Probate Court tek 1940. godine. ${ }^{24}$ Iako je već prva izvorna verzija Europske konvencije za zaštitu ljudskih prava i temeljnih sloboda iz 1950. u članku 5. postavila pravne standarde za ograničenje prava na slobodu ,,pritvaranjem umobolnika“ ${ }^{25}$ prvi slučaj u kojem su razrađene ove odredbe dobio je svoj pravni epilog pred Europskim sudom za ljudska prava (nadalje ESLJP) po proteku 27 godina od usvajanja ove Konvencije. ${ }^{26}$ Sedamdesetih godina prošloga stoljeća pojačava se i prosuđivačka aktivnost Vrhovnog suda SAD-a, koji je u više važnih slučajeva raspravljao povređuju li zakonodavne mjere i praksa zatvaranja delinkventnih i nedelikventnih osoba $\mathrm{s}$ duševnim smetnjama njihovu osobnu slobodu. ${ }^{27}$ Povećani broj riješenih predmeta rezultat je prihvaćanja liberalističkih koncepcija o vrijednosti autonomije pojedinca, ali i sazrijevanja socijalno osjetljivog društva u kojem jednakost i ravnopravnost svih članova, pa i onih koji se nose s psihičkim problemima, postaje imperativ. ${ }^{28} \mathrm{U}$ javnim i stručnim raspravama u primarnom su fokusu prava i slobode svih građana, što u ustavnopravnoj praksi dovodi do postavljanja konkretnih zahtjeva koje država mora zadovoljiti, kako bi se svako zadiranje u autonomiju pojedinca smatralo ustavnim. ${ }^{29}$

23 Legal Information Institute, Cornell University Law School, objavljeno na: <https://www.law. cornell.edu/supct/supremes.htm>, zadnji put posjećeno 1. studenog 2017.

24 Minnesota ex rel. Pearson v. Probate Court, 309 U.S. 270 (1940).

25 Council of Europe: Convention for the Protection of Human Rights and Fundamental Freedoms and Protocol, objavljeno na: <http://www.echr.coe.int/Documents/Collection Convention_1950_ENG.pdf>, zadnji put posjećeno 1. studenog 2017.

26 ESLJP, Winterwerp protiv Nizozemske, zahtjev br. 6301/73 od 24. listopada 1979.

27 Humphrey v. Cady, 405 U.S. 504 (1972), McNeil v. Patuxent Institution, 407 U.S. 245 (1972), O'Connor v. Donaldson, 422 U.S. 563 (1975), Jackson v. Indiana, 435 U.S. 975, 98 S. Ct. 1623, 56 L. Ed. 2d 69 (1978), Addington v. Texas, 441 U.S. 418 (1979), Parham v. J.R., 442 U.S. 584 (1979), Secretary of Public Welfare of Pennsylvania et al., v. Institutionalized Juveniles et al., 442 US 640 (1979).

28 O liberalizmu kao političkoj doktrini čiji je glavni cilj osigurati političke uvjete koji su neophodni kako bi se ostvarila osobna sloboda pojedinca i o drugim teorijskim promišljanjima koja nastoje definirati liberalizam vidi u: Bell, D.: What Is Liberalism?, Political Theory, vol. 42, br. 6, 2014., str. 682.-715.

29 Osim povoljnih društvenih okolnosti i odgovarajućih političkih koncepcija koje su utjecale na ustavnopravnu praksu, na određivanje jasnih i s ustavnim načelima usklađenih kriterija za prisilnu hospitalizaciju psihijatrijskih pacijenata utjecala je i jedna praktična okolnost. 
U ovome radu analizirane su odluke Ustavnog suda Republike Hrvatske od njegovog osnutka. Devedesetih godina prošloga stoljeća postojala je već dovoljno razvijena praksa ESLJP-a o pravima osoba s duševnim smetnjama, ${ }^{30}$ a na međunarodnoj razini doneseni su mnogobrojni pravni dokumenti u kojima su posebno naznačena prava ovih osoba. ${ }^{31}$ Moglo bi se stoga pretpostaviti da je bogata normativna aktivnost u komparativnom pravu bila dovoljan oslonac i putokaz da naš čuvar Ustava razvije praksu odlučivanja o ustavnosti prisilne hospitalizacije psihijatrijskih pacijenata. Iz podataka prikazanih u Grafikonu 1. proizlazi da takva pretpostavka nije u potpunosti osnovana. Naime, o ustavnosti prisilnog smještaja pacijenata koji zbog teže duševne smetnje ozbiljno i izravno ugrožavaju vlastiti ili tuđi život, zdravlje ili sigurnost, ${ }^{32}$ Ustavni sud je odlučivao u samo dva slučaja. ${ }^{33}$ Iznimno mali broj postupaka pokrenutih povodom ustavne tužbe u kojoj psihijatrijski pacijenti ističu prigovore neustavnosti njihovog lišenja slobode u psihijatrijskim ustanovama, može biti uzrokovan malim brojem prisilno hospitaliziranih pacijenata. Do sada provedena istraživanja pokazala su da prisilno smještene osobe s duševnim smetnjama participiraju u ukupnom broju

Početkom druge polovice dvadesetog stoljeća znanstvena istraživanja na području psihijatrije potvrđuju napredak u razvoju farmakoloških pripravaka. Studije pokazuju kako se uzimanjem psihofarmaka smanjuju simptomi duševne bolesti ili poremećaja kod pacijenata i povećava njihova samostalnost i bolje funkcioniranje u okruženju u kojem se nalaze. (Pinals, A. D. i Mossman, D.: Evaluation for Civil Commitment, Oxford University Press, Oxford, New York, 2012., str. 14.) Ovaj rapidni razvojni skok u terapijskim mogućnostima u psihijatriji koincidirao je s pojavom deinstitucionalizacije, reformskim modelom skrbi o psihijatrijskim pacijentima u zajednici. Primjerice, u SAD-u deinstitucionalizacija započinje 1963. godine donošenjem Mental Retardation Facilities and Community Mental Health Centers Construction Acta. (Zenoff, K. E. i Norberg, C.: Reflections on Judging in a Mental Health Court and Challenges Beyond the Courtroom Doors, Southern Illinois University Law Journal, vol. 40, 2015.-2016., str. 446.) S novom reformom, liječenje u zajednici postaje pravilo, a hospitalizacija iznimkom. U tim okolnostima neupitno se moraju usvojiti nedvosmisleni, zakonski i u skladu s Ustavom uvjeti za prisilni smještaj pacijenta u psihijatrijsku ustanovu.

30 Primjerice, ESLJP, Winterwerp protiv Nizozemske, op. cit.; ESLJP, X i Y protiv Nizozemske, zahtjev br. 8978/80 od 26. ožujka 1985.; ESLJP, Herczegfalvy protiv Austrije, zahtjev br. 10533/83 od 24. rujna 1992.; ESLJP, Johnson protiv Ujedinjenog Kraljevstva, zahtjev br. 22520/93 od 24. listopada 1997.; ESLJP, V. protiv Ujedinjenog Kraljevstva [GC], zahtjev br. 24888/94 od 16. prosinca 1999.; ESLJP, Matter protiv Slovačke, zahtjev br. 31534/96 od 5. srpnja 1999.; ESLJP, Aerts protiv Belgije, zahtjev br. 61/1997/845/1051 od 30.07.1998.

31 U sklopu međunarodne zaštite prava osoba s psihičkim problemima posebno su važni dokumenti Opće skupštine Ujedinjenih naroda, pa tako UN-ova Deklaracija o pravima mentalno retardiranih osoba od 20. prosinca 1971. godine te UN-ova Načela zaštite osoba s mentalnim oboljenjima i unapređenja zaštite mentalnog zdravlja od 17. prosinca 1991. Devedesetih godina u diskurs o zaštiti psihijatrijskih pacijenata aktivno se uključuju i psihijatrijska profesionalna udruženja. Primjerice, 25. kolovoza 1996. godine Opća skupština Svjetskog psihijatrijskog udruženja donosi Madridsku deklaraciju o etičkim standardima u psihijatrijskoj praksi koja je i danas, s nekoliko svojih izmjena i dopuna iz Hamburga (1999.), Yokohame (2002.), Kaira (2005.) i Buenos Airesa (2011.), primarni etički model za postupanje psihijatara. Godine 1997. u Oviedu pod okriljem Vijeća Europe donesena je i Konvencija o zaštiti ljudskih prava i dostojanstva ljudskog bića u pogledu primjene biologije i medicine: Konvencija o ljudskim pravima i biomedicini.

32 Čl. 22., st. 1. ZZODS/97.; čl. 27. ZZODS/14.

33 USRH, U-III-4700/2011 od 14. siječnja 2015.; USRH, U-III-2040/2016 od 7. rujna 2016. 
osoba na liječenju u psihijatrijskim ustanovama ispod $1 \%$, a iznimno rijetko ovaj broj prelazi udio od $2 \%$. No, isto tako dokazano je kako se slobodno može sumnjati u te brojke jer zbog uočenih procesnih kršenja prava osoba nad kojima se vodi postupak prisilne hospitalizacije u pojedinim slučajevima i zlouporabe instituta skrbništva nije isključeno da se do pristanka na institucionalno liječenje došlo nagovaranjem ili na neki drugi nedopušteni način. ${ }^{34}$

Zbog svega navedenog čini se da uzroci rijetkog ispitivanja ustavnosti prisilne hospitalizacije nedelinkventnih pacijenata leže negdje drugdje. Jedan od mogućih razloga može biti još nedovoljno osviještena činjenica, i kod stručnjaka mentalnog zdravlje i kod pacijenata, kako je prisilna hospitalizacija jedan od oblika ograničavanja osobne slobode. Za razliku od prisilne hospitalizacije nedelinkvenata, postupci usmjereni na određivanje prisilnog smještaja osoba, za koje je u prethodnom kaznenom postupku utvrđeno kako su u neubrojivom stanju ostvarili protupravno djelo, shvaćaju se kao više ograničavajući i po osobnu slobodu pogubniji. Na donošenje ovakvih zaključaka zasigurno utječu duži zakonski rokovi prisilnog smještaja delinkvenata od ostalih psihijatrijskih pacijenata, ali i prihvaćanje sustavne cjelovitosti kaznenog i izvanparničnog postupka u slučaju postupanja prema neubrojivim osobama. ${ }^{35}$ Stoga ne iznenađuje podatak da se Ustavni sud u najvećem broju slučajeva iz uzorka upravo bavio preispitivanjem povrede prava prisilno hospitaliziranih neubrojivih pacijenata (37,1 \% svih razmatranih slučajeva).

Analiza prikupljenih odluka i rješenja pokazala je kako je najveći broj preostalih postupaka vođen povodom ustavnih tužbi o povredi prava osoba koje su djelomično ili u potpunosti lišene poslovne sposobnosti (22,6 \% slučajeva). Podatci su očekivani jer je potpuno lišenje poslovne sposobnosti u kontekstu pravnih odnosa neka vrst socijalne smrti, a djelomično lišenje vrsta socijalnog sakaćenja, budući da su po svom pravnom učinku izvor ovisnosti o drugima i teškog ograničenja prava na privatnost $\mathrm{i}$ na samoodređenje. Ostala prava osoba s duševnim smetnjama (imovinska i roditeljska prava, prava djece s duševnim smetnjama te prava žrtava u kaznenom postupku), bila su iznimno rijetko u fokusu našega najvišeg sudišta. To, s jedne strane ukazuje na raznolikost pravnih pitanja kojima se ovo sudište bavilo, ali i na okolnost da ne postoji neko određeno pravo koje je predmet učestalog i teškog kršenja. Ovakve zaključke ipak treba uzeti uz određenu rezervu zbog relativno malog broja razmatranih slučajeva u uzorku. Mali broj predmeta snažna je poruka o stanju prava psihijatrijskih pacijenata u Republici Hrvatskoj.

Iako bi se zbog dobivenih rezultata na prvi pogled moglo lako zaključiti kako osobe s duševnim smetnjama nesmetano uživaju svoja prava u Republici Hrvatskoj,

34 Grozdanić V., Tripalo, D., op. cit., str. 804.-805.

35 Glava VII. Postupak prisilnog smještaja prema neubrojivim osobama i osuđenicima, ZZODS/97.; Glava VII. Prisilni smještaj i liječenje na slobodi neubrojive osobe, ZZODS/14. $\mathrm{O}$ reformi koja je u hrvatski pravni prostor uvela jedinstvenu koncepciju kaznenopravnog i civilnog postupanja prema opasnim neubrojivim osobama vidi u: Đurđević, Z.: Kritičkoporedbeni osvrt na pravni položaj počinitelja s duševnim smetnjama u Republici Hrvatskoj, Hrvatska pravna revija, 2002., str. 66.-80.; Goreta, M. i dr. Indikacije za forenzični tretman smanjeno ubrojivih i neubrojivih počinitelja kaznenih djela (1998-2002), Hrvatski ljetopis za kazneno pravo i praksu, vol. 14, br. 1, 2007., str. 16.-18. 
a ako i dođe do njihove povrede, pravni mehanizmi učinkovito djeluju, pa u konačnici nema potrebe podnositi ustavne tužbe, ovakvi zaključci bili bi samo jedno paušalno pojednostavljivanje cijele situacije. Naime, rezultati do sada provedenih istraživanja upozorili su na česta kršenja prava osoba s duševnim smetnjama. U nekim psihijatrijskim bolnicama i ustanovama socijalne skrbi njihovi korisnici borave u nehumanim i skučenim uvjetima lišeni adekvatne pomoći zbog nedovoljnog broja stručnog osoblja. ${ }^{36}$ Osobama na liječenju u psihijatrijskim ustanovama ne daje se na uvid njihova medicinska dokumentacija, ${ }^{37}$ a često je ta ista dokumentacija nepotpuna, nejasna i u pogledu nekih pitanja, kao što je pitanje (ne)postojanja sposobnosti pacijenta za informirani pristanak na medicinske postupke, vođena ,po špranci““. ${ }^{38}$ Uočeni su i primjeri proceduralnih kršenja prava pacijenta tijekom prisilne hospitalizacije koji ne uspijevaju ostvariti kontakt sa sucem i sa svojim odvjetnikom. ${ }^{39}$ Osobe u odnosu na koje se vodio postupak prisilnog smještaja nisu bile upozorene na svoja zakonska prava, nije ih se pozivalo na rasprave, a spis njihovog predmeta vođen je površno i neprofesionalno. ${ }^{40} \mathrm{Na}$ povrede prava osoba s duševnim smetnjama upozorio je i UN-ov Odbor za prava osoba s invaliditetom u Zaključnim primjedbama o Inicijalnom izvješću Hrvatske. Između ostalog, Odbor je izrazio zabrinutost zbog prisilnog zadržavanja i smještanja osoba s invaliditetom na osnovi invaliditeta $\mathrm{u}$ ustanove. Nadasve alarmantnim smatrao je postojanje prakse prisilnog zadržavanja osoba s mentalnim oštećenjem i intelektualnim teškoćama bez njihovog pristanka. Poseban je problem često korištenje nedobrovoljnih postupaka i mjera sputavanja te ostalih oblika ponižavajućeg postupanja kao i medicinskih postupaka bez prethodnog pristanka pacijenta u ustanovama socijalne skrbi i u psihijatrijskim ustanovama. ${ }^{41} \mathrm{U}$ okolnostima u kojima se često krše njihova prava, nije isključeno da psihijatrijski pacijenti nisu dovoljno informirani o svojim pravima i nemaju znanje o mogućim pravnim mehanizmima koje mogu pokrenuti kako bi im se omogućila adekvatna pravna zaštita. Istraživanja u drugim zemljama pokazala su kako $38 \%$ anketiranih pacijenata ne koriste svoja prava upravo jer ne posjeduju znanje o njima. ${ }^{42}$ Breme stigme i zaziranje društva od psihijatrijskih pacijenata zbog njihove potencijalne ili

36 Republika Hrvatska, Pučki pravobranitelj: Izvješće o ljudskim pravima osoba s duševnim smetnjama u psihijatrijskim ustanovama u okviru djelovanja Nacionalnog preventivnog mehanizma u 2014. godini, Zagreb, 2015., str. 8.-10., 23.

37 Republika Hrvatska, Pučki pravobranitelj: Izvješće Pučke pravobraniteljice za 2016. godinu, Zagreb, 2017., str. 137.-138.

38 Republika Hrvatska, Pravobranitelj za osobe s invaliditetom: Izvješće o radu Pravobraniteljice za osobe s invaliditetom za 2016. godinu, Zagreb, 2017., str. 34.-35.

39 Mental Disability Advocacy Center i Udruga za društvenu afirmaciju osoba s duševnim smetnjama (SJAJ): Daleko od očiju, Ljudska prava u psihijatrijskim bolnicama i ustanovama socijalne skrbi u Hrvatskoj, Budimpešta, Zagreb, 2011., 40.-43.

40 Đurđević, Z.: Pravni okvir za primjenu prisilne hospitalizacije: regulativa i kritički osvrt, objavljeno u: Štrkalj-Ivezić, S. (ur.): Medicinski i pravni okvir za hospitalizaciju osoba s duševnim smetnjama, Smjernice za primjenu prisilne hospitalizacije u praksi, Hrvatski liječnički zbor, Udruga Svitanje, Zagreb, 2011., str. 27.-34.

41 UN-ov Odbor za prava osoba $\mathrm{s}$ invaliditetom, Zaključne primjedbe o Inicijalnom izvješću Hrvatske, CRPD/C/HRV/CO/1 od 17. travnja 2015.

42 Diseth, R. R., op. ct., str. 12.-13. 
izražene opasnosti još je jedan od razloga koji ovu skupinu građana baca na margine društva. Predrasude o osobama s psihičkim smetnjama dijele obični građani, ali i pojedinci uključeni $\mathrm{u}$ institucije $\mathrm{u}$ sustavu mentalnog zdravlja. ${ }^{43} \mathrm{U}$ takvim okolnostima od presudne je važnosti osigurati kvalitetnu zaštitu temeljnih prava onih koji su među nama najslabiji, a pokretanje postupaka pred Ustavnim sudom kruna je takve zaštite. Je li u svojoj dosadašnjoj praksi naše najviše sudište uspjelo osigurati ovakvu zaštitu, posebno će se istražiti u poglavljima koja slijede.

\section{USTAVNOPRAVNA ZAŠTITA POJEDINIH PRAVA OSOBAS DUŠEVNIM SMETNJAMA}

\subsection{Ocjena suglasnosti zakonskih odredbi s Ustavom}

U članku 125. Ustava Republike Hrvatske detaljno je regulirana nadležnost Ustavnog suda. ${ }^{44}$ Prema odredbama ovoga članka, između ostalog, zadaća je Ustavnog suda odlučivati o suglasnosti pojedinih zakonskih odredbi s Ustavom kao i o suglasnosti drugih propisa s Ustavom i zakonom. Kao zaštitnik vladavine prava, naše najviše sudište odlučuje i povodom ustavnih tužbi, nakon što su iscrpljena sva redovita i izvanredna pravna sredstva, protiv pojedinačnih odluka tijela i pravnih osoba s javnim ovlastima kada su tim odlukama povrijeđena ljudska prava i temeljne slobode građana ili pravo na lokalnu i područnu (regionalnu) samoupravu. U nadležnosti je Ustavnog suda obavljati i druge poslove naznačene u Ustavu, no apstraktna kontrola ustavnosti i zakonitosti pravnih normi i konkretno preispitivanje odluka tijela koja obnašaju javne ovlasti putem instituta ustavne tužbe, putovi su kojima je inicirano ustavno sudovanje kako bi se pružila ustavnopravna zaštita prava i položaja osoba s duševnim smetnjama. ${ }^{45}$

\subsubsection{Ustavnost ZZODS/97}

Postoji li osnova mijenjati zakonske odredbe kojima se regulira status ili neko od prava građana s mentalnim problemima zbog njihove materijalne ili formalne neustavnosti, Ustavni sud je raspravljao u tri različita predmeta ${ }^{46}$ Kako bi se sud upustio u ocjenu ustavnosti zakonskih normi potrebno je ispuniti određene pretpostavke, tzv. pretpostavke o biti stvari. Osim što po svojoj određenosti norma koju ispituje Ustavni sud mora biti zakonska odnosno podzakonska, isto tako se traži da se radi o važećoj

43 Doak, D. D.: Theorizing Disability Discrimination in Civil Commitment, Texas Law Review, vol. 93, 2014.-2015., str. 1589.-1590.

44 Čl. 125. Ustava Republike Hrvatske, NN 56/1990., 135/1997., 113/2000., 28/2001., 76/2010., 5/2014.; vidi isto tako čl. 34.-76. Ustavnog zakona o Ustavnom sudu Republike Hrvatske, NN 99/1999., 29/2002.

45 O vladavini prava i nadzoru ustavnosti i zakonitosti koji provodi Ustavni sud vidi u: Smerdel, B., op. cit. 121.-138.; Krapac, D.: Postupak pred Ustavnim sudom Republike Hrvatske, Ustrojstvo i proceduralni elementi ustavnog nadzora, Narodne novine, Zagreb, 2014.

46 USRH, U-I-422/1999 od 13. listopada 1999.; USRH, U-I-677/2011 od 27. siječnja 2015.; USRH, U-I-2695/2012 i dr. od 28. rujna 2015. 
pravnoj normi koja ima određeni sadržaj, a donesena je u formalno prihvatljivom postupku. Nakon što je preispitao postojanje ovih pretpostavki, u predmetu U-I677/2011 Ustavni sud je rješenjem odbacio prijedlog za pokretanje postupka za ocjenu suglasnosti s Ustavom ZZODS/97 iz razloga što navedeni zakon više nije bio na snazi. ${ }^{47} \mathrm{U}$ trenutku donošenja rješenja, započeo je s važenjem ZZODS/14 pa se nisu ispunile pretpostavke za odlučivanje o biti stvari. Iako se ovakvom obrazloženju i izreci nema što prigovoriti, neupitno je da je od podnošenja prijedloga za ocjenu ustavnosti do donošenja ovog rješenja proteklo više od tri godine. Radi se o proteku vremena, šutnji ustavnog sudišta, koja ga pravno ne obvezuje, jer sve dok Ustavni sud ne donese rješenje o pokretanju postupka za ocjenu ustavnosti povodom prijedloga, ovaj postupak nije niti pokrenut. ${ }^{48} \mathrm{U}$ slučaju da je ovakvo rješenje i doneseno, rok od godine dana od pokretanja postupka za ocjenu ustavnosti u kojem bi sud, u pravilu, trebao odlučiti o prihvaćenom prijedlogu, samo je instruktivne naravi. Zbog pravnog uređenja početka ovog postupka i instruktivnog roka u kojem se očekuje donošenje pravorijeka, dosadašnja praksa pokazala je kako Ustavni sud zna donositi odluke i rješenja u vremenu koje ima političku konotaciju s notom arbitrarnosti. ${ }^{49}$ Uočena pravna praksa snažan je indikator političke odgovornosti sudaca i važan predmet javne i znanstvene rasprave. U ovom konkretnom slučaju, dopuštanjem da vrijeme teče bez konkretne ocjene osnovanosti prijedloga za ocjenu ustavnosti, Ustavni sud je propustio donijeti odluku o glavnom normativnom sadržaju kojim se uređuje položaj i prava osoba s duševnim smetnjama te samo formalno riješio predmet. ${ }^{50}$

\subsubsection{Standardi postupanja policijskih djelatnika s osobama $s$ duševnim smetnjama}

Za razliku od prethodno analiziranog predmeta, Ustavni sud se upustio u ocjenu ustavnosti zakonske odredbe ZZODS/97 u predmetu U-I-422/1999. ${ }^{51}$ Iako je u ovom predmetu sud donio rješenje kojim se ne prihvaća prijedlog za pokretanje postupka za ocjenu ustavnosti, što bi trebalo značiti da sud nije odlučivao o biti stvari, u samom obrazloženju rješenja može se pronaći tumačenje osporavanog članka 24. ZZODS/97 u kojem je propisana ovlast policijskih službenika da postupaju s osobama s duševnim smetnjama. Prema ovoj odredbi, u osobito žurnim slučajevima, policijskim djelatnicima dana je ovlast dovoditi u nadležnu psihijatrijsku ustanovu osobe s duševnim smetnjama ako postoji osnovana sumnja da takve osobe mogu

47 USRH, U-I-677/2011, op. cit.

48 Čl. 42., st. 2. Ustavnog zakona o Ustavnom sudu Republike Hrvatske, op. cit.

49 Barić, S.: The Transformative Role of the Constitutional Court of the Republic of Croatia: From the ex-Yu to the EU, Analitika - Center for Social Research, Sarajevo, 2016., str. 34.-35.

50 Iz obrazloženja citiranog rješenja proizlazi kako je isti predlagatelj podnio novi prijedlog za pokretanje postupka za ocjenu suglasnosti ZZODS/14 23. srpnja 2014. godine. Ako se Ustavni sud upusti u razmatranje prihvatljivosti ovoga prijedloga i ocjenu ustavnosti novog ZZODS-a, za sud će biti to nova prilika izvršiti kontrolu rada zakonodavca i osigurati hijerarhijsku usklađenost zakonskih normi s Ustavom, a za osobe s duševnim smetnjama i građane Republike Hrvatske dobiti konkretne upute o kvaliteti zakonskog uređenja položaja i prava psihijatrijskih pacijenata.

51 USRH, U-I-422/1999, op. cit. 
neposredno ugroziti vlastiti život ili zdravlje odnosno život ili zdravlje drugih bez prethodnog liječničkog pregleda. Postavilo se pitanje je li tada važeće zakonsko rješenje protivno članku 22. Ustava u kojem se garantira nepovredivost slobode i osobnosti svih građana i dopušta njihovo ograničenje jedino zakonom na temelju odluke suda. ${ }^{52}$ Naime, prema mišljenju podnositelja, policijski službenici nisu se mogli smatrati sudom, a njihova diskrecijska ovlast lišenja slobode bila je pretjerano ograničavajuća jer se odnosila na sve osobe koje pate od duševne smetnje, a ne samo na one s težim duševnim smetnjama. Sporan je bio i dio odredbe koji je omogućavao uskratu prava na slobodu psihijatrijskog pacijenta bez prethodnog konzultiranja liječnika, a na temelju „osnovane sumnje“. Dovođenje osobe s duševnim problemima u psihijatrijsku ustanovu treba se smatrati uhićenjem, a nikoga se ne može uhititi bez pismenog, sudbenog i na zakonu utemeljenog naloga. ${ }^{53}$

Iznijeti navodi u prijedlogu nisu uvjerili sud u neustavnost sporne odredbe. Stajalište je suda da su situacije dovođenja osoba s duševnim smetnjama u psihijatrijsku ustanovu ,izuzetne i potencijalno opasne situacije, kada je zbog ugrožavanja života ili zdravlja potrebno žurno postupanje." U takvim okolnostima ne može se inzistirati na postupanju po nalogu o ograničenju slobode, niti na procjeni policijskog službenika koja bi se temeljila na sveobuhvatnom, medicinskom znanju. Postupanje po osnovanoj sumnji prihvatljivi je pravni standard čija uporaba, tumačenje i značenje u kontekstu članka 24. ZZODS/97 nisu sporni. Ustavni sud također je naglasio kako se dovođenje ne može izjednačiti s uhićenjem niti pritvaranjem unatoč tomu što se radi o obliku ograničenja slobode..$^{54}$

Analiza izloženog pokazuje da je Ustavni sud izgradio taktiku tumačenja sporne odredbe na iznošenju suprotnih stavova od onih koje je naveo podnositelj prijedloga. Primjerice, podnositelj je mišljenja da se dovođenje osobe s duševnom smetnjom treba smatrati uhićenjem, dok Ustavni sud tvrdi da takvim zaključcima nema mjesta. Dok podnositelj osporava postupanje policijskih djelatnika po osnovanoj sumnji, naše najviše sudište smatra kako je osnovana sumnja prihvatljiv i nesporan pravni standard. U takvom tumačenju izostala je sadržajna analiza koja bi putem ustavnopravnih standarda objasnila zašto država ima pravo dovesti osobu s duševnom smetnjom u psihijatrijsku ustanovu i zašto takvo ograničenje slobode nije protivno načelu razmjernosti. Naime, odlučujući o sadržaju dovođenja, Ustavni sud je trebao procijeniti opći interes društva da se osobu s duševnom smetnjom za koju se osnovano sumnja da je opasna po vlastiti ili tuđi život ili zdravlje liši slobode i suprotstaviti ga s pojedinačnim interesom te osobe da joj se ne ograničava sloboda. Kojem interesu treba dati prednost ovisit će o odgovorima na četiri osnovna pitanja. ${ }^{55}$

52 Čl. 22., st. 1. i 2. Ustava Republike Hrvatske, op. cit. „Čovjekova je sloboda i osobnost nepovrediva. Nikomu se ne smije oduzeti ili ograničiti sloboda, osim kada je to određeno zakonom, o čemu odlučuje sud."“

53 Čl. 24., st. Ustava Republike Hrvatske, op. cit. „Nitko ne može biti uhićen ili pritvoren bez pismenoga, sudbenog i na zakonu utemeljenog naloga. Takav nalog mora biti pročitan i uručen uhićeniku prilikom oduzimanja slobode.“

54 USRH, U-I-422/1999, op. cit.

55 Barak, A.: Proportionality, Constitutional Rights and their Limitations, Cambridge University Press, Cambridge, 2012., str. 3. 
Prema prvom pitanju sud je trebao provjeriti postoji li u zakonu posebno propisana svrha za ograničenjem prava. Sam sadržaj ispitivanog članka 24. ZZODS/97 pokazuje kako je svrha dovođenja psihijatrijskog pacijenta za kojeg se osnovano sumnja da je opasan u psihijatrijsku ustanovu, otkloniti tu istu opasnost. ${ }^{56}$ Nakon ovakvog zaključka, sud je trebao ispitati postoji li racionalna veza između dovođenja kao zakonske mjere kojom se postavlja ograničenje slobode i odgovarajuće svrhe. Upravo navođenjem argumenata kako policijski službenici ne posjeduju medicinsko znanje i kako se ograničenje slobode dovođenjem provodi kako bi se osobi pružila stručna medicinska pomoć, Ustavni sud je trebao afirmativno odgovoriti i na ovo drugo pitanje. U narednom koraku načelo razmjernosti nalaže sudu ocijeniti je li mjera dovođenja u psihijatrijsku ustanovu nužna, odnosno postoji li neka druga alternativna mjera kojom se na sličan način može postići ista svrha s manjim stupnjem ograničenja. Razlozi koje je sud navodio obrazlažući kako je policijsko dovođenje hitan postupak, opravdavaju nužnost ograničenja slobode. ${ }^{57},{ }^{58}$ Zbog okolnosti koje zahtijevaju žurnu reakciju policijskih službenika ne može se opravdano očekivati da bi se drugim, po osobnu slobodu manje invazivnim mjerama, kao što je to izdavanje liječničke uputnice po pregledu liječnika obiteljske medicine, mogla postići svrha dovođenja. U konačnici, Ustavni sud je trebao ocijeniti postoji li stricto sensu razmjernost odnosno primijeniti test balansiranja važući, s jedne strane, interes društva za dovođenjem osobe s duševnom smetnjom u psihijatrijsku ustanovu, pod uvjetom da je s dovoljnim stupnjem sumnje utvrđena njezina opasnost, i s druge, interes te osobe da joj se prisilno ne ograničava osobna sloboda. Vaganjem ovih dvaju interesa prevagu odnosi interes društva. Takav zaključak Ustavni sud nije jasno izrekao, no moglo ga se naslutiti u dijelu obrazloženja rješenja o pravnoj prirodi prisilne hospitalizacije i policijskog dovođenja.

56 U pravnoj teoriji prihvaćen je interes države da otklanja opasnost koju osoba s duševnom smetnjom predstavlja za sebe ili druge. Prema postavkama teorije parens patriae država ima pravo zaštititi dobrobit osobe koja je opasna po sebe samu. U slučaju da pojedinac zbog svoje duševne smetnje dovodi u opasnost druge građane, pravo države na provođenje prisilnih mjera proizlazi iz njezinih policijskih ovlasti kojima ih štiti od protupravnih djela. McCure, J. A.: Psychiatric Boarding in New Hampshire: Violation of a Statutory Right to Treatment, University of New Hampshire Law Review, vol. 14, br. 1, 2015., str. 201.; Simon, J. i Rosenbaum, S. A.: Dignifying Madness: Rethinking Commitment Law in an Age of Mass Incarceration, University of Miami Law Rreview, vol. 70, 2015.-2016., str. 8.-9.

57 Šezdesetih godina prošloga stoljeća većina sjevernoameričkih država u svojem zakonodavstvu uredila je postupke tzv. „hitnog građanskog pritvaranja“ (engl. emergency commitment procedures). Takvi su postupci bili pravni mehanizam koji je dozvoljavao lišenje slobode osobe za koju se vjerovalo da je opasna za sebe ili druge ili da postoji potreba za njezinim psihijatrijskim liječenjem jer bi u suprotnome nastale nepopravljive posljedice. Ovakve postupke mogli su provoditi policijski službenici ili liječnici, a ograničenje slobode osobe nad kojom se provodio postupak opravdavalo se većom rizičnošću situacije u kojoj se nad takvim pacijentom ne bi primijenila mjera prisile u odnosu na rizik koji nosi privremeni gubitak pacijentove slobode. Kopel, D. B. i Cramer, C. E.: Reforming Mental Health Law to Protect Public Safety and Help the Severely Mentally Ill, Howard Law Journal, vol. 58, br. 3, 2015., str. 749.-750.

58 Oduzimanje slobode u hitnim slučajevima bez liječničkog mišljenja prihvaća i ESLJP, no pod uvjetom da se konzultacije s liječnikom pribave odmah po lišenju slobode. ESLJP, Varbanov protiv Bugarske, zahtjev br. 31365/96 od 5. listopada 2000.; ESLJP, M.S. protiv Ujedinjenog Kraljevstva, zahtjev br. 24527/08 od 3. svibnja 2012. 
Naime, prisilna hospitalizacija (prisilno zadržavanje i prisilni smještaj) na zakonu je zasnovan sudski postupak kojim se može ograničiti i oduzeti sloboda psihijatrijskog pacijenta, a policijsko dovođenje je u biti zakonska mjera koja je uistinu određeno ograničenje slobode, no čijom primjenom dolazi do pokretanja mehanizama zaštite te iste slobode. Naime, prema odredbama ZZODS/97, psihijatar koji primi dovedenu osobu u psihijatrijsku ustanovu bio je dužan donijeti odluku o njezinom otpuštanju ili prisilnom zadržavanju u roku od 72 sata od njezinog dovođenja. ${ }^{59}$ Odluku o prisilnom zadržavanju psihijatrijska ustanova morala je bez odgode, odnosno u roku ne dužem od 12 sati od njezinog donošenja, dostaviti nadležnom županijskom sudu koji će provesti

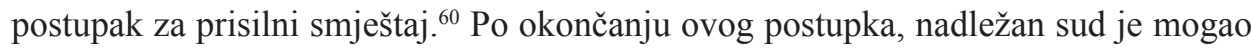
naložiti prisilni smještaj psihijatrijskog pacijenta rješenjem, ako su se za takvo što ispunili određeni zakonski uvjeti ili njegovo otpuštanje iz psihijatrijske ustanove ${ }^{61} \mathrm{U}$ konačnici, postupkom prisilne hospitalizacije štiti se sloboda psihijatrijskih pacijenata jer se time onemogućuje njihovo arbitrarno zatvaranje od strane drugih državnih tijela.

Unatoč uočenim suštinskim manjkavostima, analizirano je rješenje prvi pravni akt u kojem je Ustavni sud postavio standarde za policijsko postupanje u odnosu na osobe s duševnim smetnjama. Naime, sud je jasno naglasio kako „se od (policijskih) službenika objektivno može očekivati ... postupanje i ponašanje koje u najvećoj mjeri poštiva osobu i prava duševno bolesne osobe u slučaju kada se osnovano posumnja da ta osoba može ugroziti sebe ili drugog." ${ }^{62}$ Ovakav zaključak u skladu je s praksom ESLJP-a koji je upozorio da su policijski službenici dužni postupati u skladu s dostojanstvom osoba s duševnim smetnjama, posebice u onim slučajevima kada pribjegavaju primijeni fizičke prisile. ${ }^{63}$ Primjena fizičke sile koja nije nužno

59 Čl. 25. ZZODS/97.

60 Čl. 27., st. 1. ZZODS/97.

61 Čl. 22. ZZODS/97.

62 USRH, U-I-422/1999, op. cit.

63 Za razliku od Ustavnog suda Hrvatske i ESLJP-a, Vrhovni sud SAD-a u svojoj dosadašnjoj praksi nije zauzeo jasan stav o kakvoći policijskih mjera prisile nad osobama s duševnim smetnjama. Predmetno pravno pitanje pojavilo se u slučaju City and County of San Francisco, California, et ll. v. Sheehan, 575 U.S. _ (2015). U fokusu razmatranja našao se para. 12132. Glave II. Zakona o Amerikancima s invaliditetom (Americans with Disability Act) kojim se zabranjuje njihova diskriminacija. Stručna i šira javnost očekivala je da će sud odgovoriti na pitanje može li se ova odredba tumačiti na način da iz nje proizlaze pozitivne obveze države zbog kojih „policijski službenici trebaju prilagoditi svoje postupanje naoružanoj, nasilnoj i duševno bolesnoj osobi pri uhićenju“. Odgovor nije dan iz razloga što tužitelj nije razvio pravnu argumentaciju u smjeru tvrdnji da se predmetna odredba „ne primjenjuje na policijske djelatnike koji su suočeni s naoružanim i opasnim pojedincem“ zbog kojih je Vrhovni sud i prihvatio razmotriti predmet odobrivši certiorari. No, sud se nije zaustavio na ovakvim tvrdnjama, već je upravo iz činjenice da dužnost prilagodbe mjera prisile nije jasno utvrđena zaključio kako policijski službenici imaju kvalificirani imunitet od odgovornosti za povrede nanesene osobi s duševnim smetnjama pri uhićenju. Ovakvo pravno prosuđivanje naišlo je na oštre kritike (Pecorini, M.: Trying to Fit a Square Peg into a Round Hole: Why Title II of the Americans with Disabilities Act Must Apply to All Law Enforcement Services, Journal of Law and Policy, vol. 24, br. 2, 2016., str. 553.-554.), između ostalog i zbog činjenice da postoji 60 \% veća vjerojatnost da će policijski djelatnici pri postupanju lišiti života osobu s duševnom smetnjom koja nije uključena u psihijatrijski tretman, no nekog drugog građanina (Levin, R.: 
potrebna zbog ponašanja osobe s duševnom smetnjom umanjuje ljudsko dostojanstvo i nečovječno je i ponižavajuće postupanje protivno članku 3. EK-a. ${ }^{64}$ Materijalni aspekti ovoga članka bit će povrijeđeni i ako primijenjene mjere prisile po svom intenzitetu prelaze u zlouporabu ovlasti policijskih djelatnika jer je njihova intervencija bila nerazmjerna otporu osobe s duševnom smetnjom. ${ }^{65}$ Svaki izostanak provođenja učinkovite istrage o pritužbama osobe $\mathrm{s}$ duševnom smetnjom da su djelatnici policije postupali ne poštivajući njezino dostojanstvo protivno članku 3. EK-a, dovest će do povrede prava iz ovoga članka u procesnom segmentu. ${ }^{66}$ Isto tako, kada je policijskim službenicima od ranije poznato da osoba kojoj ograničavaju slobodu pati od duševnog poremećaja, obvezni su poduzeti posebne mjere kako bi se izbjegli rizici inherentni lišenju slobode takve osobe. ${ }^{67}$ Obveza postupati u skladu s dostojanstvom osobe $\mathrm{s}$ duševnom smetnjom traje sve dok se ona nalazi u vlasti policijskih službenika. ${ }^{68}$

\subsubsection{Biračka prava osoba s duševnim smetnjama}

O pravu glasovanja osoba s duševnim smetnjama Ustavni sud je bio pozvan raspraviti u predmetu U-I-2695/2012 i dr. iz 2015. godine. ${ }^{69}$ Grupa podnositelja prijedloga za ocjenu ustavnosti osporavala je članak 4., stavak 1. Zakona o izboru zastupnika u Hrvatski sabor u dijelu u kojem je ona isključivala aktivno biračko pravo „... onih koji su pravomoćnom sudskom odlukom lišeni poslovne sposobnosti."“70 Scenarij zabilježen u prethodno analiziranom slučaju (U-I-677/2011), ponovio se i u ovom predmetu. Naime, Ustavni sud je odbio raspravljati o postojanju i pravnoj prirodi prava građana kojima je pravomoćnom sudskom odlukom oduzeta poslovna sposobnost da biraju saborske zastupnike jer je sporni dio odredbe ukinuo sam zakonodavac. Budući da se od stupanja na snagu zakonskih izmjena i dopuna ZIZHS-a iz 2015. godine biračima smatraju svi punoljetni hrvatski državljani, ${ }^{71}$ Ustavni sud je zaključio kako su prestale postojati pretpostavke za odlučivanje o biti stvari te je prijedlog za ocjenu ustavnosti odbacio rješenjem.

Iako je ovakvim formalnim zaključkom aktivno biračko pravo ostalo neopterećeno u cijelosti, ustavni sud je $\mathrm{u}$ istom predmetu zauzeo stav kako se pasivno biračko pravo osobe kojoj je oduzeta poslovna sposobnost može ograničiti. Naime,

Responsiveness to Difference: ADA Accommodations in the Course of an Arrest, Stanford Law Review, vol. 69, 2017., str. 269., 271.).

64 ESLJP, V.D. protiv Republike Hrvatske, zahtjev br. 15526/10 od 8. studenog 2011.; ESLJP, Ilievska protiv Bivše jugoslavenske Republike Makedonije, zahtjev br. 20136/11 od 7. svibnja 2015.

65 ESLJP, Rupa protiv Rumunjske, zahtjev br. 58478/00 od 16. prosinca 2008.; isti standard primijenit će se i kada policijski službenici primjenjuju pretjeranu silu prema osobi koja se opire, a za koju sumnjaju da pati od duševne smetnje. ESLJP, R.L. i M.-J.D. protiv Francuske, zahtjev br. 44568/98 od 19. svibnja 2004.

66 ESLJP, Kucheruk protiv Ukrajine, zahtjev br. 2570/04 od 6. rujna 2007.

67 ESLJP, Rupa protiv Rumunjske, op. cit.

68 ESLJP, M.S. protiv Ujedinjenog Kraljevstva, op. cit.

69 USRH, U-I-2695/2012 i dr., op. cit.

70 Zakon o izborima zastupnika u Hrvatski sabor, NN 116/1999., 109/2000., 53/2003., 167/2003., 44/2006., 19/2007., 20/2009., 145/2010., 24/2011. i 93/2011. (ZIZHS/99).

71 Zakon o izmjenama i dopunama ZIZHS-a, NN 19/2015. 
sud je zaključio kako mora poštovati odluku zakonodavca da saborskom zastupniku oduzimanjem poslovne sposobnosti pravomoćnom sudskom odlukom tijekom obnašanja mandata prestaje i zastupnički mandat. ${ }^{72}$ Glavni argument suda zasniva se na ocjeni da se ovdje radi o prihvatljivom ograničenju pasivnog biračkog prava, jer prije nego što mu je oduzeta poslovna sposobnost, saborski zastupnik je već ostvario pravo biti biran. Drugim riječima, pravna ograničenja aktivnog i pasivnog biračkog prava koja se nameću osobama bez poslovne sposobnosti mogu dovesti do različitog opterećenja njihovog prava glasovanja. Primjerice, ako se osobi lišenoj poslovne sposobnosti oduzme pravo birati zastupnike u predstavničkom tijelu, takvo je opterećenje teže i u potpunosti briše biračko pravo, za razliku od oduzimanja zastupničkog mandata gdje je ono prihvatljivo jer se biračko pravo u segmentu da se zastupnika bira, već ispunilo. Ovakva pravna argumentacija može se podvrći kritici jer se slijedeći isti argumentacijski niz također može zaključiti kako su na svim parlamentarnim izborima koji su se održali prije oduzimanja poslovne sposobnosti osobe imale pravo birati zastupnike, pa je i takvo ograničenje prihvatljivo.

Dodatni argumenti kojima se Ustavni sud služi kako bi opravdao gubitak mandata oduzimanjem poslovne sposobnosti, i dalje bitno ne objašnjavaju pravnu prirodu ograničenja prava pojedinca da ga se bira. Sud ističe kako ne postoji zajednički pristup ovom pitanju među europskim državama i kako je u ovlasti zakonodavca da zakonom uređuje biračko pravo hrvatskih državljana, ${ }^{73}$ što samo po sebi neminovno povlači i ovlast uređivanja pojedinih ograničenja toga prava. Isto tako, domašaj članka 16. Ustava u kojem se propisuju ustavnopravni standardi za ograničenje sloboda i prava građana dovoljno je širok za uravnoteženu regulaciju političkih prava osoba lišenih poslovne sposobnosti, a prestanak mandata zastupnika zbog oduzimanja poslovne sposobnosti uvjetovan je i ovisan o pravomoćnoj sudskoj odluci. Činjenica da ne postoji konsenzus u europskom pravnom prostoru oko opterećivanja glasačkih prava građana trebao je biti dodatan signal čuvaru Ustava da o ovom pravnom problemu zauzme jasan stav nakon detaljne analize i primjene načela razmjernosti i testa balansiranja u široj slobodnoj procjeni. ${ }^{74}$ Pritom treba imati na umu da je propisivanje ograničenja biračkog prava u zakonu samo prvi korak u ocjenjivanju njegove ustavnosti kojeg nalaže načelo razmjernosti. Široki doseg načela razmjernosti, a bez da se ono primijenilo u ocjenjivanju opterećenja nekog prava, sam po sebi ništa ne govori je li usvojeno zakonsko ograničenje uistinu razmjerno. Argument o oduzimanju poslovne sposobnosti sudskom odlukom u postupku u kojem su poštovane garancije pravičnog suđenja govori o mogućoj prihvatljivosti ograničenja prava na privatnost

72 Čl. 10., toč. 2. ZIZHS-a.

73 O ustavnom uređenju biračkih prava osoba s duševnim smetnjama u drugim državama vidi u: Raub, A. i dr.: Constitutional Rights of Persons with Disabilities: An Analysis of 193 National Constitutions, Harvard Human Rights Journal, vol. 29, 2016., str. 229.-235.

74 Zbog izostanka uniformnoga zakonskog rješenja o ograničavanju biračkog prava na europskoj razini, naš zakonodavac ima širu slobodnu procjenu kako urediti ovo pravno pitanje. Takvo što proizlazi iz bogate prakse ESLJP-a koji je više puta naglasio kako kod zakonskog uređivanja pitanja oko kojih ne postoji konsenzus među državama članica Vijeća Europe te kod osjetljivih moralnih i etičkih pitanja, država ima široku slobodnu procjenu (eng. wide margin of appreciation). 
i samoodređenje osobe s duševnom smetnjom, a ne i o ograničenju njezina pasivnog biračkog prava. Zbog svega navedenoga čini se opravdanim zaključiti kako je naše ustavno sudište primijenilo jedan formalistički pristup u sagledavanju glasačkih prava osoba s duševnim smetnjama bez konkretnog raspravljanja o njihovoj prirodi i dosegu mogućih opterećenja od strane države. No, takav pristup dovoljno ne rasvjetljava problematiku prava osoba s duševnim smetnjama da biraju i budu birane u predstavničkom tijelu kao jednog od temeljnih političkih prava građana. ${ }^{75}$

\subsection{Zaštita prava osoba s duševnim smetnjama u postupcima pokrenutim ustavnom tuz̆bom}

\subsubsection{Pravo na osobnu slobodu i sigurnost i pravo na pravično suđenje tijekom prisilne hospitalizacije}

O mogućim povredama prava na osobnu slobodu i sigurnost psihijatrijskih pacijenata u postupcima prisilne hospitalizacije Ustavni sud Republike Hrvatske odlučivao je u predmetima U-III-4700/2011 te U-III-2040/2016. ${ }^{76}$ U prvom slučaju, sud je postupao po ustavnoj tužbi podnositeljice koja je osporavala osnovanost prvostupanjskog i drugostupanjskog rješenja Županijskog suda u Osijeku na temelju kojih joj je naložen boravak u psihijatrijskoj ustanovi protiv njezine volje sukladno odredbama ZZODS/97. Najvažniji prigovori podnositeljice istaknuti u ustavnoj tužbi odnose se na manjkavu i neprofesionalno vođenu liječničku dokumentaciju, nedovoljno utvrđeno činjenično stanje, a posebice okolnost njezine nasilnosti, kao i pasivnost suca koji nije ispunio svoju dužnost da posjeti podnositeljicu u psihijatrijskoj ustanovi u roku od tri dana od njezinog zadržavanja. ${ }^{77}$ Navedeni prigovori odnose se na povredu prava na slobodu i sigurnost iz članka 22. Ustava te prava na pravično

75 Ustavnopravni teoretičari tako upozoravaju da se o biračkim pravima osoba s duševnim smetnjama treba raspravljati uzimajući u obzir različite ideološke interpretacije koncepata sudjelovanja građana u izborima, njihove uloge u sustavu vlasti i temeljne političke i društvene vrijednosti u državi. Pritom treba imati na umu da se ,političke zajednice reflektiraju u usvojenim ustavnopravnim instrumentima“. (McHugh, J. T.: Idiots and Insane Persons: Electoral Exclusion and Democratic Values within the Ohio Constitution, Albany Law Review, vol. 76, br. 4, 2013., str. 2191.) Jedan od putokaza u raspravama o biračkim pravima građana s mentalnim problemima zasigurno trebaju biti i stavovi teoretičara o članku 29. Konvencije o pravima osoba s invaliditetom u kojem se regulira pravo na sudjelovanje u političkom i javnom životu ove skupine građana. (Korać Graovac, A. i Čulo, A.: Konvencija o pravima osoba s invaliditetom - novi pristup shvaćanju prava osoba s duševnim smetnjama, Zbornik Pravnog fakulteta u Zagrebu, vol. 61, br. 1, 2011., str. 83.-84.) Kao jedna od mogućih smjernica može poslužiti i komparativna analiza biračkih prava osoba s mentalnim poremećajima u drugim zemljama. (Ryan, T. i dr.: Voting with an 'Unsound Mind'? A Comparative Study of the Voting Rights of Persons with Mental Disabilities, UNSW Law Journal, The University of New South Wales Law Journal, 2016., vol. 9, br. 3, str. 1038.-1071.)

76 USRH, U-III-4700/2011 od 14. siječnja 2015.; USRH, U-III-2040/2016 od 7. rujna 2016.

77 Sukladno čl. 30., st. 2. ZZODS/97 „Sudac... je (dužan) bez odgode, a najkasnije u roku od 72 sata od primitka obavijesti o prisilnom zadržavanju, prisilno zadržanu osobu posjetiti u psihijatrijskoj ustanovi i ako je to s obzirom na njezino zdravstveno stanje moguće, obaviti s njom razgovor." Gotovo identičnu odredbu propisuje i čl. 36., st. 1. ZZODS/14. 
suđenje iz članka 29., stavak 1. Ustava. ${ }^{78}$ Analiza odluke kojom se ustavna tužba odbija pokazuje kako se naše najviše sudište nije posebno bavilo povredom prava na slobodu već je svoju pozornost usmjerilo na navodne povrede prava da „... zakonom ustanovljeni... sud pravično... odluči o... pravima i obvezama (građana)“. Također je uočeno da se u predmetnoj odluci dobro ne navode nazivi rješenja kojima je ograničena sloboda podnositeljice. Iako se prema roku na koji je određeno prisilno liječenje može zaključiti kako podnositeljica osporava rješenje o prisilnom smještaju, ${ }^{79}$ Ustavni sud u izreci i obrazloženju odluke govori o rješenju o prisilnom zadržavanju. Slično, u predmetu U-III-2040/2016 podnositeljica je isticala prigovore o izostanku konkretnih razloga za određivanje prisilnog smještaja u psihijatrijskoj ustanovi prema ZZODS/14, no i ovoga puta ustavno sudište je razmatralo osnovanost ustavne tužbe samo s polazišta vezanih uz pravo na pravično suđenje. Zbog uočenih nelogičnosti posebno se upozorava na općeprihvaćene ustavnopravne standarde zaštite slobode psihijatrijskih pacijenata.

U ustavnopravnoj teoriji i praksi prisilna hospitalizacija osoba s duševnim smetnjama smatra se velikim opterećenjem za njihovu osobnu sigurnost i slobodu. U većem broju različitih odluka Vrhovni sud SAD-a naglasio je kako se smještaj osobe u psihijatrijsku ustanovu treba smatrati ,masivnim ograničavanjem slobode (eng. a massive curtailment of liberty). ${ }^{80}$ Iako do sada niti u jednom slučaju Ustavni sud Njemačke nije raspravljao o ustavnosti prisilne hospitalizacije, u predmetu 2 BvR 882/09 koji se odnosio na opravdanost prisilnog davanja lijekova psihijatrijskim pacijentima, zauzeo je stav da prisilni smještaj pacijenta u psihijatrijsku ustanovu predstavlja ,osobito ozbiljno zadiranje u temeljno pravo osobe na tjelesni integritet" ${ }^{6.81}$ Imajući u vidu težinu koju prisilno zadržavanje i prisilni smještaj imaju po temeljna prava pojedinca, ESLJP je u predmetu Winterwerp protiv Nizozemske ${ }^{82}$ prvi put postavio standarde koji se moraju ispuniti kako bi prisilna hospitalizacija bila u skladu s člankom 5., stavak 1., točka e) EK-a. ${ }^{83}$

Članak 5. EK-a garantira pravo na slobodu i osobnu sigurnost svim građanima država članica Konvencije. Stoga je svako lišenje slobode iznimno i kao takvo može uslijediti samo nakon što se provede postupak u skladu sa zakonom. Jedan od

78 Čl. 22. i 29., st. 1. Ustava Republike Hrvatske, op. cit.

79 Iz obrazloženja o činjenicama i okolnostima predmeta saznaje se da je podnositeljica prisilno zadržana u psihijatrijskoj klinici 8. kolovoza 2011. godine. Budući da joj je prvostupanjskim rješenjem Županijskog suda u Osijeku određen prisilni boravak u toj klinici do 7. rujna 2011. godine radi poduzimanja mjera liječenja, ovim rješenjem se nije mogao odrediti nastavak prisilnog zadržavanja koje prema čl. 30., st. 3. ZZODS/97 može trajati najviše osam dana, već samo prisilni smještaj.

80 Humphrey v. Cady, op. cit.; Vitek v. Jones, 445 U.S. 480 (1980); Suprotno izdvojeno mišljenje suca Brennana, s kojim su se složili suci Marshall i Blackmun u predmetu Jones v. United States, 463 U.S. 354 (1983); Podudarno izdvojeno mišljenje suca Stewarta u predmetu Zinermon v. Burch, 494 U.S. 113 (1990).

81 Odluka njemačkog Ustavnog suda od 23. ožujka 2011. godine, 2 BvR 882/09.

82 ESLJP, Winterwerp protiv Nizozemske, op. cit.

83 Čl. 5., st. 1., toč. e) EK-a: „Svatko ima pravo na slobodu i na osobnu sigurnost. Nitko se ne smije lišiti slobode, osim u sljedećim slučajevima i u postupku propisanom zakonom... ako se radi o pritvaranju umobolnika." 
taksativno navedenih slučajeva u kojima se pod ovim uvjetima nekome može oduzeti sloboda jeste i „pritvaranje umobolnika“. Pojam umobolnika ušao je u Konvenciju kao medicinsko-pravni pojam koji se uobičajeno koristio u europskom diskursu pedesetih godina prošloga stoljeća, no danas kao takav nije prihvatljiv. ${ }^{84}$ Stoga ne čudi da je već u slučaju Winterwerp sud naglasio kako se ovaj pojam ne može definirati jer se njegovo značenje stalno razvija napretkom psihijatrijskih istraživanja, većom fleksibilnošću psihijatrijskih tretmana i mijenjanjem odnosa društva prema duševnim bolestima i duševno bolesnim pacijentima. ${ }^{85} \mathrm{U}$ skladu $\mathrm{s}$ ovakvim zaključkom, ESLJP je postavio tri materijalno-pravna i procesno-pravna zahtjeva koji se moraju zadovoljiti pri svakoj prisilnoj hospitalizaciji. Pod materijalno-pravnim uvjetima traži se da prisilno hospitalizirana osoba pati od duševne smetnje čija priroda i intenzitet nalažu nužnost ili poželjnost liječenja u psihijatrijskoj ustanovi, a takvo što proizlazi iz liječničkog mišljenja. ${ }^{86}$ Po vrsti i intenzitetu duševna smetnja mora biti takva da dovodi u opasnost sebe ili po druge. Isto tako potrebno je da je prisilna hospitalizacija $\mathrm{u}$ interesu osobe $\mathrm{s}$ duševnom smetnjom ili u interesu javnog poretka. Za razliku od materijalno-pravnih uvjeta, procesno-pravne pretpostavke odnose se i na kvalitetu postupka u kojem je donesena odluka o lišenju slobode psihijatrijskog pacijenta. Kao prvi uvjet ESLJP ističe zahtjev prema kome ocjena zakonitosti prisilnog smještaja treba biti u nadležnosti suda. ${ }^{87} \mathrm{U}$ postupku ocjene sud treba preispitati je li ograničenje slobode psihijatrijskog pacijenta poduzeto kako bi se postigla svrha propisana $\mathrm{u}$ zakonu. ${ }^{88}$ Prisilna hospitalizacija moći će se produžavati sve dok traje duševna smetnja

84 O problematici definiranja pojma umobolnika odnosno osobe nezdravog uma vidi u: BabićBosanac, S.: Zaštita prava na slobodu prisilno hospitaliziranih duševno oboljelih osoba pod okriljem članka 5. Europske konvencije o zaštiti ljudskih prava i temeljnih sloboda, Pravni vjesnik, vol. 25, br. 1, 2009., str. 49.-51.

85 Iako u slučaju Winterwerp sud nije zauzeo konkretan stav tko se ima smatrati duševno bolesnom osobom, jasno je upozorio da se pod okriljem ovog pojma ne mogu lišiti slobode oni građani čiji se stavovi o ponašanju ne podudaraju sa stavovima većine u društvu. Isto je zaključio i Vrhovni sud SAD-a kada je upozorio da „netolerancija ili animozitet javnosti sami po sebi ne mogu ustavnopravno opravdati oduzimanje fizičke slobode pojedincima... koji su fizički neprivlačni ili se ponašaju na društveno ekscentričan način.“ ( $O^{\prime}$ Connor v. Donaldson, op. cit.). Isto tako, država nema pravo oduzeti slobodu građanima smještajem u ustanove samo i isključivo na osnovu njihovog invaliditeta proizašlog iz duševne smetnje. (Olmstead v. Georgia Department of Human Resources, 527 U.S. 581 (1999)).

86 U Winterwerp predmetu ESLJP je jasno naznačio koje su to uloge suda, a koje liječnika vještaka u postupku prisilne hospitalizacije. Slično, zaključuje i sudac White u suprotnom izdvojenom mišljenju tvrdeći kako „načini i postupci koje provode liječnici tijekom dijagnostičkih postupaka ne smiju biti posao sudaca." Pennhurst State School and Hospital v. Halderman, 451 U.S. 1 (1981).

87 Jedan od prvih zakonskih akata u kojem su sadržane odredbe o nužnosti provođenja sudskog postupka kako bi se ustanovilo treba li osobu s duševnom smetnjom prisilno lišiti slobode zbog provođenja psihijatrijskog liječenja donesen je 1880. godine u državi Wisconsin. Po okončanju sudskog postupka odluku o prisilnoj hospitalizaciji donosila je porota (Humphrey v. Cady, op. cit.).

88 Konkretne ustavnopravne smjernice kako ocijeniti je li zatvaranje povezano sa svrhom proklamiranom u zakonu dao je Vrhovni sud SAD-a u predmetu Jackson v. Indiana, op. cit. Mišljenje je suda da priroda i trajanje samog zatvaranja moraju biti u racionalnoj vezi sa svrhom zatvaranja. 
zbog koje je potrebno osobu prisilno psihijatrijski liječiti. ${ }^{89}$

Navedeni zahtjevi su temeljni standardi zaštite osobne slobode osoba s duševnim smetnjama, i kao takvi zadržali su se u novijoj praksi ESLJP-a. ${ }^{90}$ Tijekom godina, oni su se učvršćivali i upotpunjavali novim zahtjevima ovisno o okolnostima prisilnih hospitalizacija podnositelja zahtjeva. Primjerice, pravilo koje dopušta upućivanje osobe na prisilno institucionalno liječenje zbog duševne smetnje koju je utvrdio liječnik nadopunjeno je zahtjevom da liječnik duševnu smetnju mora utvrditi prema aktualnom psihičkom stanju osobe, a ne isključivo prema prošlim događajima. ${ }^{91}$ Liječnički nalaz i mišljenje, pa i onda ako osoblje psihijatrijske bolnice oduzima slobodu pacijentu vjerujući kako je to u njegovu najboljem interesu, nisu dovoljni, jer se svaka prisilna hospitalizacija bez proceduralnih garancija smatra arbitrarnim zatvaranjem psihijatrijskih pacijenata..$^{92}$ Odgovornost liječničkog osoblja koje postupa u najboljoj namjeri proizlazi iz standarda da je razborito očekivati da su psihijatri trebali znati da prisilnim zatvaranjem u psihijatrijskoj ustanovi, bez da je o tomu donesena sudska odluka, pacijentu oduzimaju slobodu. ${ }^{93}$ Da bi psihijatrijsko vještačenje bilo valjano, u pravilu se traži da nalaz i mišljenje o (ne)postojanju duševne smetnje i potrebe za prisilnim liječenjem izradi psihijatar zaposlen izvan psihijatrijske ustanove u kojoj je pacijent lišen slobode. ${ }^{94} \mathrm{U}$ načelu će se oduzimanje slobode osobi s duševnim smetnjama smatrati ,zakonitim“u svrhu poštovanja članka 5., stavak 1., točka e, jedino ako se osobu smjesti u bolnicu, kliniku ili u drugu odgovarajuću ustanovu. Uvjeti u ustanovi ne smiju biti u suprotnosti sa svrhom koja se zatvaranjem nastoji postići. ${ }^{95}$ Tijekom prisilne hospitalizacije potrebno je redovno ispitivati psihičko stanje pacijenta kako bi se ustanovilo postoji li i dalje potreba za prisilnim liječenjem. ${ }^{96}$ Iako je moguće oduzeti slobodu i osobama za koje se sumnja da boluju od duševne smetnje pa ih se zatvara kako bi se njihovo psihičko stanje ispitalo, oduzimanje slobode zbog opservacije ne smije biti beskonačno. ${ }^{97}$ Isto tako,

89 Većina istaknutih standarda za provođenje prisilne hospitalizacije iz Winterwerp slučaja mogu se pronaći u predmetu Vrhovnog suda SAD-a Minnesota ex rel. Pearson v. Probate Court, op. cit. Sud je zaključio kako je prisilno institucionalno liječenje „ludih osoba“ i „osoba s psihopatskom osobnošću“ u skladu s Ustavom pod uvjetom da su takve osobe zbog svog psihičkog stanja opasne jer „postoje dokazi da nemaju nikakvu moć kontrole nad svojim seksualnim porivima ili da će vjerojatno napasti ili na drugi način nanijeti ozljedu, štetu, bol ili drugo zlo (drugima) ...". Država, naime ima pravo staviti pod svoju kontrolu pojedince koji u zajednici predstavljaju element opasnosti. Kontrola je izjednačena s ograničavanjem slobode prisilnom hospitalizacijom pacijenta o kojoj odluku donosi sud na temelju mišljenja dvaju liječnika.

90 Bartlett, P. i dr.: Mental Disability and the European Convention on Human Rights, Martinus Nijhoff Publishers, Leiden, Boston, 2007., str. 42.-44.

91 ESLJP, Varbanov protiv Bugarske, op. cit.; ESLJP, Shtukaturov protiv Rusije, zahtjev br. 44009/05 od 27. lipnja 2008.

92 ESLJP, H.L. protiv Ujedinjenog Kraljevstva, zahtjev br. 45508/99 od 5. listopada 2004.; O'Connor v. Donaldson, op. cit.

93 O'Connor v. Donaldson, ibid.

94 ESLJP, X. protiv Finske, zahtjev br. 34806/04 od 3. srpnja 2012.

95 ESLJP, L.B. protiv Belgije, zahtjev br. 22831/08 od 2. listopada 2012.

96 ESLJP, Stanev protiv Bugarske, zahtjev br. 36760/06 od 17. siječnja 2012.

97 McNeil v. Patuxent Institution, op. cit. 
jednom kada se takva sumnja otkloni liječničkim pregledom, osoba se mora pustiti na slobodu. Svako produživanje zatvaranja, pa i ono koje traje samo nekoliko sati, zbog administrativnih razloga povreda je prava na osobnu slobodu. ${ }^{98}$ Arbitrarno ograničenje slobode pacijenta je i ono ograničenje nastalo prisilnim smještajem u psihijatrijsku ustanovu protivno odluci suda koji je pacijenta uputio na prisilno liječenje na slobodi. ${ }^{99}$ Prisilni smještaj u psihijatrijsku ustanovu je toliko teška mjera da ju se može opravdati jedino ako se nakon razmatranja drugih, manje pogubnih mjera po osobnu slobodu pacijenta, zaključilo da bi one bile neučinkovite u zaštiti pojedinca ili javnog interesa. ${ }^{100}$ Država ne samo što ima negativne obveze suzdržati se od arbitrarnog zatvaranja građana u državnim psihijatrijskim klinikama, pravo na osobnu slobodu i sigurnost je toliko važno da pred državu postavlja pozitivne obveze zaštititi građane od prisilnog liječenja u privatnim psihijatrijskim ustanovama. ${ }^{101}$

Zbog važnosti prava na slobodu kao jednog od visoko pozicioniranog prava na hijerarhijskoj ljestvici osobnih ljudskih prava i sloboda, osobe lišene slobode smještajem u psihijatrijskim klinikama, sukladno članku 5., stavak 4. EK-a, imaju pravo pokrenuti sudski postupak u kojem će se brzo odlučiti o zakonitosti smještaja ili o njihovom puštanju na slobodu ako je prisilni smještaj bio nezakonit. ${ }^{102}$ Takav bi postupak trebao zadovoljavati kriterije pravičnog suđenja, iako proceduralne garancije zbog duševne smetnje nositelja prava mogu u određenoj mjeri odstupati od garancija koje građani imaju u građanskim i kaznenim postupcima. ${ }^{103}$ Odstupanja nikako ne smiju biti takva da pred osobu s duševnom smetnjom postavljaju dodatne barijere na putu aktiviranja sudske zaštite kao što bi to bilo pribavljanje pozitivne ocijene posebne komisije da je osnovan zahtjev za sudskom kontrolom. ${ }^{104}$ Neprihvatljivo je i neopravdano odgađanje suda da odluči o zahtjevu osobe da je se otpusti iz psihijatrijske

98 ESLJP, R.L. i M.-J.D. protiv Francuske, op. cit.; ESLJP, M.S. protiv Ujedinjenog Kraljevstva, op. cit.; ESLJP, Nowicka protiv Poljske, zahtjev br. 30218/96 od 3. prosinca 2002.

99 ESLJP, Shopov protiv Bugarske, zahtjev br. 11373/04 od 2. rujna 2010.

100 ESLJP, Plesó protiv Mađarske, zahtjev br. 41242/08 od 2. listopada 2012.

101 ESLJP, Storck protiv Njemačke, zahtjev br. 61603/00 od 16. lipnja 2005. Više o odluci u: Gusy, C. i Müller, S.: The Protection of Marginalised Individuals and Minorities in Germany: The Role of National and European Judicial Mechanisms, objevljeno u: Anagnostou, D. i Psychogiopoulou, E. (ur.): The European Court of Human Rights and the Rights of Marginalised Individuals and Minorities in National Context, Martinus Nijhoff, Leiden, Boston, 2010., str. 108.

102 Čl. 5., st. 4. EK-a, op. cit.

103 Čl. 6., st. 1. EK-a, op. cit. ESLJP, Winterwerp protiv Nizozemske, op. cit. Pravo na pravično suđenje priznato je psihijatrijskim pacijentima i u praksi Vrhovnog suda SAD-a. (Addington v. Texas, op. cit.; O'Connor v. Donaldson, op. cit.) Jedan od razloga zašto i ova grupa građana treba imati pravo na pravično suđenje leži u činjenici da okolnosti medicinske prirode nikako ne smiju biti osnova za lišenje procesnih garancija građana. (Vitek v. Jones, op. cit.) Isto tako pravo na psihijatrijsko liječenje ne smije se tumačiti na način da ono izbriše pravo pacijenta na pravično suđenje. (Podudarno izdvojeno mišljenje suca Burgera u predmetu O'Connor v. Donaldson, op. cit.) O važnosti prava na pravično suđenje onih kojima se ograničava sloboda najbolje govori rečenica suca Brennana kako „nije izumljen niti jedan bolji instrument koji će nas dovesti do istine od onog da se osobi u opasnosti od ozbiljnog oduzimanja (slobode) pruže činjenice o slučaju... i prilika da ih se ospori.“ (Podudarno i suprotno izdvojeno mišljenje suca Brennana u predmetu Parham v. J.R., op. cit.).

104 ESLJP, Aerts protiv Belgije, op. cit. 
ustanove. ${ }^{105}$ Zaštitna proceduralna pravila odnose se na tek započeto oduzimanje slobode koje bi u hrvatskom pravu odgovaralo prisilnom zadržavanju, započet prisilni smještaj, ali i na preispitivanje prisilnih smještaja koji već neko vrijeme traju. ${ }^{106}$

Pravo na pristup sudu treba biti osigurano i psihijatrijskim pacijentima koji zbog svog psihičkog stanja ne mogu iskazati informirani pristanak na hospitalizaciju. Bilo bi u potpunosti pogrešno prihvatiti presumpciju kako se takve osobe dobrovoljno smještaju u psihijatrijske ustanove. ${ }^{107}$ Dobrovoljnim se ne može smatrati niti smještaj osoba kojima je oduzeta poslovna sposobnost jer je na njihovo prisilno liječenje suglasnost dao skrbnik. ${ }^{108}$ Isto tako, sudska zaštita se nikako ne smije uskratiti ovoj skupini građana samo zato što na pokretanje sudskog postupka za ispitivanje osnovanosti prisilnog liječenja nije pristao i njihov skrbnik. ${ }^{109}$ Sudski postupak ne smije biti uređen na način da se teret dokazivanja nezakonitosti prisilne hospitalizacije prebaci na osobu s duševnim smetnjama. ${ }^{110}$ Psihijatrijskim pacijentima koji se liječe $\mathrm{u}$ psihijatrijskim klinikama protiv svoje volje u sudskim postupcima treba biti pružena prilika da ih se čuje osobno ili putem zastupnika. Priliku da ih se sasluša na sudu posebice treba dati osobama s duševnim smetnjama u predmetima u kojima postoje oprečni zaključci psihijatrijskih vještaka o njihovu psihičkom stanju. ${ }^{111}$ Odvjetnik psihijatrijskog pacijenta treba zastupati njegove interese $\mathrm{u}$ skladu $\mathrm{s}$ pravilima pravničke struke i biti aktivna stranka u postupku. Zbog neaktivnosti odvjetnika, sudski postupak se može proglasiti arbitrarnim i nepravičnim. ${ }^{112}$ Do istog rezultata može dovesti i pasivnost suca koji samo formalno vodi postupak za preispitivanje zakonitosti prisilne hospitalizacije tijekom iznimno kratke rasprave. ${ }^{113}$

Istaknuti ustavnopravni standardi upućuju na zaključak kako je primarno pravo pacijenta koje se ograničava prisilnom hospitalizacijom pravo na osobnu slobodu i sigurnost. Upravo što je tijekom prisilnog boravka pacijentu oduzeta sloboda, dolazi do daljnjih ograničenja njegovih prava, pa tako prava na privatnost, prava na samoodređenje i osobnu autonomiju, prava na tjelesni integritet, prava na udruživanje i drugih prava. ${ }^{114}$ Zbog nametanja pacijentima da se njihov život odvija na način koji sami nisu odabrali tijekom smještaja u psihijatrijskoj ustanovi, ograničenje slobode prelijeva se preko ostalih prava i sloboda poput plimnog vlada. Kako bi se ispitala osnovanost izvornog poremećaja koji je izazvao val ograničenja, ustavno pravo poznaje posebne proceduralne standarde koji osobama na prisilnom liječenju garantiraju pravo

105 ESLJP, Hutchison Reid protiv Ujedinjenog Kraljevstva, zahtjev br. 50272/99 od 20. veljače 2003.

106 ESLJP, Winterwerp protiv Nizozemske, op. cit.; ESLJP, Stanev protiv Bugarske, op. cit.; O'Connor v. Donaldson, op. cit.; Addington v. Texas, op. cit.

107 Zinermon v. Burch, op. cit.

108 ESLJP, Shtukaturov protiv Rusije, op. cit.

109 ESLJP, Stanev protiv Bugarske, op. cit.

110 ESLJP, Hutchison Reid protiv Ujedinjenog Kraljevstva, op. cit.

111 ESLJP, Romanov protiv Rusije, zahtjev br. 63993/00 od 20. listopada 2005.

112 ESLJP, M.S. protiv Republike Hrvatske br. 2., zahtjev br. 75450/12 od 19. veljače 2015.

113 ESLJP, Shtukaturov protiv Rusije, op. cit.

114 Doak, D. D., op. cit., str. 1589. Detaljnu listu prava koja se ograničavaju prisilno hospitaliziranim psihijatrijskim pacijentima iznio je i sudac Brennan u podudarnom i suprotnom izdvojenom mišljenju u predmetu Parham v. J.R., op. cit. 
na pristup sudu, a jednom kada sud počinje raspravljati o osnovanosti ograničenja ovog prava, pravo na pravično suđenje. Stoga nije dovoljno ispitati ustavne tužbe u kojima se prisilno hospitalizirani pacijenti pozivaju na činjenice koje bacaju sumnju na opravdanost prisilnog smještaja samo s pozicije prava na pravično suđenje, kao što je to učinio Ustavni sud u predmetima U-III-4700/2011 i U-III-2040/2016. ${ }^{115}$ Osim što se takvim pristupom neopravdano sužava ustavnopravna zaštita, lako se može zaključiti kako se na takav način i unaprijed bezrazložno pretpostavlja da je svaki prisilni boravak u psihijatrijskoj ustanovi zakonit i šalje pogrešna poruka kako je osobama s duševnim smetnjama mjesto u takvim ustanovama. Takvo što posebice proizlazi iz dijela obrazloženja odluke u kojem ustavno sudište potvrđuje da je podnositeljičin navod o propustu suca da je posjeti u psihijatrijskoj ustanovi prema članku 30., stavak 2. ZZODS/97 osnovan, ${ }^{116}$ no unatoč tomu ,sudac pojedinac je ipak obavio telefonski razgovor s liječnikom... i informirao se o zdravstvenom stanju pacijentice u kojem je obaviješten da postupak mora biti pokrenut“, pa „,.. ipak nije došlo do povrede nekog od njezinih ustavnih prava." "117 Postupak prisilne hospitalizacije osmišljen je kao učinkovit zakonodavni mehanizam u kojem se u periodičnim razmacima temeljito ispituju ograničenja slobode pacijenata. Bilo kakvo prihvaćanje pasivnosti glavnoga kontrolora i rukovoditelja tog mehanizma svojevrsni je podbačaj u implementaciji zakonodavnih odredbi, ali i snažna indikacija da je došlo do povrede prava na osobnu slobodu podnositeljice u proceduralnom smislu.

\subsubsection{Ograničenje prava djelomičnim ili potpunim lišenjem poslovne sposobnosti}

Uočena pasivnost Ustavnog suda u ocjeni ustavnosti oduzimanja slobode prisilnom hospitalizacijom zamijećena je i u predmetima koje je sud rješavao povodom ustavne tužbe zbog oduzimanja poslovne sposobnosti osobama s duševnim smetnjama. Primjerice, u svojim prvim odlukama o tom pitanju ustavno sudište je rješenjem odbacilo ustavne tužbe kao nedopuštene jer su ih podnosile osobe u potpunosti lišene poslovne sposobnosti bez saznanja i odobrenja skrbnika. ${ }^{118}$ Gotovo deset godina kasnije, naše najviše sudište mijenja svoj stav. Pozivajući se na ustavnopravno načelo da EK kao živući instrument treba tumačiti u svjetlu uvjeta koji danas postoje u društvu i činjenicu da je ESLJP u svojoj novijoj praksi priznao pravo na podnošenje pojedinačnih zahtjeva osobama bez poslovne sposobnosti, Ustavni sud je prihvatio aktivnu legitimaciju podnositelja i ustavne tužbe proglasio dopuštenima. ${ }^{119}$ Naime, svrha oduzimanja poslovne sposobnosti leži u zaštiti psihičkog, tjelesnog i socijalnog zdravlja osobe, ${ }^{120}$ odnosno u sprječavanju situacija da osobe pod skrbništvom sklapaju

115 USRH, U-III-4700/2011, op. cit.; USRH, U-III-2040/2016 op. cit.

116 Vidi supra bilješku 77.

117 USRH, U-III-4700/2011, ibidem.

118 USRH, U-I-1525/2006 od 3. srpnja 2008.; USRH, U-I-1845/2006 od 15. studenog 2006.

119 USRH, U-I-796/2012 od 6. svibnja 2015.; USRH, U-I-4536/2012 od 14. siječnja 2016.; USRH, U-I-1380/2014 od 20. svibnja 2015.

120 USRH, U-I-4536/2012, op. cit. 
ugovore $\mathrm{i}$ vode postupke na svoju štetu, ${ }^{121}$ a podnošenje pojedinačnih zahtjeva ESLJP-u i ustavnih tužbi Ustavnom sudu, nije u suprotnosti s tom svrhom. ${ }^{122}$

Oduzimanje i ograničenje poslovne sposobnosti iznimno je teška mjera jer ,... poslovna sposobnost predstavlja pravo na život u punom smislu. " 123 Iz tog razloga takve postupke javnih vlasti prema pojedincima treba sagledati s pozicija poštovanja njihova ljudskog dostojanstva i osobne autonomije. ${ }^{124}$ Ovakav zaključak našeg ustavnog sudišta u skladu je s pristupom Vrhovnog suda SAD-a koji je preispitivao moguće povrede prava osoba s psihičkim smetnjama tražeći odgovore na pitanje je li država ispunila obvezu poštovanja njihovog dostojanstva. ${ }^{125}$ Identičan ustavnopravni put primijenjen je i u presudama ESLJP-a. ${ }^{126} \mathrm{~S}$ obvezom poštovanja ljudskog dostojanstva u uskoj su vezi daljnja dva prava koja se ograničavaju djelomičnim ili potpunim nepriznavanjem poslovne sposobnosti osobama koje se nose s psihičkim problemima, pravom na privatnost i pravom na pravično suđenje.

Prema članku 35. Ustava, svakome se jamči štovanje i pravna zaštita njegova osobnog života. ${ }^{127}$ Pravo na privatnost proklamirano u ovome članku pred državu postavlja negativne i pozitivne obveze. Naime, država je dužna suzdržati se od mjera koje bi nepotrebno opteretile privatnu sferu života pojedinca, ali isto tako mora poduzeti i pozitivne korake kako bi se ostvarilo ustavno jamstvo sadržano u članku 35. Ustava. ${ }^{128}$ Postupanje u skladu s negativnim obvezama ovisit će o ocjeni je li ograničenje ili oduzimanje poslovne sposobnosti kojim se zadire u privatnost osobe

121 ESLJP, Zehentner protiv Austrije, zahtjev br. 20082/02 od 16. srpnja 2009.; ESLJP, A.N. protiv Litve, zahtjev br. 17280/08 od 31. svibnja 2016.

122 Ucrtani smjer u pružanju pojačane pravne zaštite osobama s duševnim smetnjama ESLJP je nastavio širiti odobravanjem locusa standi i nevladinim udrugama koje podnose zahtjeve u ime osoba s duševnim smetnjama tražeći zaštitu njihovih prava. ESLJP, Centre for Legal Resources on Behalf of Valentin Câmpeanu protiv Rumunjske, zahtjev br. 47848/08 od 17. srpnja 2014.

123 USRH, U-I-4536/2012, op. cit. Na teške posljedice ograničenja poslovne sposobnosti upozoravaju i teoretičari. Vidi tako: Flynn, E. i Arstein-Kerslake, A.: The Support Model of Legal Capacity: Fact, Fiction, or Fantasy?, Berkeley Journal of International Law, vol. 32, br. 1, 2014., str. 125.-126.

124 USRH, U-I-1380/2014, op. cit.

125 Primjerice, u podudarnom izdvojenom mišljenju u predmetu Cleburne v. Cleburne Living Center iz 1985. godine, sudac Marshall, s kojim su se složili suci Brennan i Blackmun, naglasio je kako u američkom društvu postoje mnogobrojne barijere koje sprječavaju priznavanje dostojanstva i individualnosti osobama s mentalnom retardacijom. Cleburne v. Cleburne Living Ctr., 473 U.S. 432 (1985)

126 ESLJP, M.S. protiv Republike Hrvatske br. 2., op., cit.; ESLJP, M.S. protiv Ujedinjenog Kraljevstva, op. cit.; ESLJP, Romanov protiv Rusije, zahtjev br. 63993/00 op. cit.; A.N. protiv Litve, op. cit.

127 Čl. 35. Ustava Republike Hrvatske, op. cit. „Svakomu se jamči štovanje i pravna zaštita njegova osobnog i obiteljskog života, dostojanstva, ugleda i časti.“

$128 \mathrm{U}$ ustavnopravnoj teoriji i praksi nisu unaprijed određene posebne obveze koje država ima štiteći pravo na privatnost psihijatrijskih pacijenata. Takve obveze određuju se od slučaja do slučaja ovisno o svim konkretnim okolnostima. U predmetima vezanim uz ograničenje poslovne sposobnosti pitanje ispunjenja pozitivnih obveza može se pojaviti kod procjene je li ograničenje bilo nužno, odnosno je li se u ispunjenju pozitivnih obveza moglo pronaći manje restriktivno sredstvo po pravo na privatnost. 
s duševnom smetnjom u skladu s načelom razmjernosti iz članka 16. Ustava. ${ }^{129} \mathrm{U}$ predmetima koji su se odnosili na potpuno lišenje poslovne sposobnosti osoba $\mathrm{s}$ duševnom smetnjom, Ustavni sud je primijenio načelo razmjernosti ispitivanjem svih relevantnih zahtjeva ovog načela. U prvome koraku sud je ustanovio kako je primarna svrha stavljanja osoba $\mathrm{s}$ psihičkim problemima pod skrbništvo zaštita prava i njihove dobrobiti, a takvu svrhu proklamiraju relevantne odredbe Obiteljskog zakona. Ograničenje privatnosti i autonomije pojedinca koncipirano u mjeri lišenja poslovne sposobnosti pravno je sredstvo kojim se postiže navedena legitimna svrha. Brisanje poslovne sposobnosti da bi bilo razmjerno, mora biti i nužno, a takvo što će se postići jedino ako u konkretnom slučaju ne postoji neka druga, alternativna manje pogubna mjera po pravo na privatnost i samoodređenje. I konačno, oduzimanje poslovne sposobnosti bit će razmjerno ako se njime postiže valjani balans između interesa pojedinca da mu se ne opterećuje pravo na privatnost i interesa države ga se stavi pod skrbništvo. U slučaju izostanka samo jednog od navedena četiri zahtjeva, oduzimanje ili ograničenje poslovne sposobnosti smatrat će se neustavnim. ${ }^{130}$

Zbog posljedica koje mjere određivanja skrbnika mogu imati po privatnost, samoodređenje i osobnu autonomiju osobe s duševnom smetnjom, postupak povodom ograničenja poslovne sposobnosti mora zadovoljiti garancije pravičnog suđenja. ${ }^{131}$ Takve garancije postojat će ako odluku o ograničenju donese neovisni i nepristrani sud u razumnom roku poštivajući načelo jednakosti oružja između stranaka. Ad contrario, izostanak samo jedne od navedenih garancija dovest će do nepravičnog postupka. Primjerice, jednake proceduralne pozicije izostat će ako se osobi o čijoj se poslovnoj sposobnosti odlučuje ne pruži mogućnost da osobno sudjeluje u raspravi pred sudom ili se ne osigura kontradiktornost postupka. ${ }^{132}$ Ako osoba s duševnim smetnjama nije u mogućnosti prisustvovati ročištu, kontradiktornost se treba postići aktivnim uključivanjem u raspravu njezinog pravnog zastupnika ili posebnog skrbnika. ${ }^{133}$ Izričito formalno sudjelovanje posebnog skrbnika u postupku koje se u suštini svelo na primjedbu da mu ,činjenično stanje nije poznato pa (da iz) opreza radi osporava navode iz prijedloga za lišenje poslovne sposobnosti“ $i$ da ,nema primjedbi na nalaz i mišljenje vještaka" ne postiže ovu kontradiktornost i može rezultirati povredom prava na pravično suđenje. ${ }^{134}$ Povreda ovog prava nastat će i ukoliko se za posebnog skrbnika postavi djelatnik istog onog centra za socijalnu skrb koji je i podnio prijedlog za pokretanje postupka lišenja poslovne sposobnosti. ${ }^{135}$ Do istog ishoda može dovesti i pasivnost centra za socijalnu skrb jer, nakon što pokrene postupak za ograničenje

129 Čl. 16. Ustava Republike Hrvatske, op. cit. „Slobode i prava mogu se ograničiti samo zakonom da bi se zaštitila sloboda i prava drugih ljudi te pravni poredak, javni moral i zdravlje. Svako ograničenje slobode ili prava mora biti razmjerno naravi potrebe za ograničenjem u svakom pojedinom slučaju.“"

130 USRH, U-I-1380/2014, op. cit.; USRH, U-I-4536/2012, op. cit.

131 Čl. 29., st. 1. Ustava Republike Hrvatske, op. cit. „Svatko ima pravo da zakonom ustanovljeni neovisni i nepristrani sud pravično i u razumnom roku odluči o njegovim pravima i obvezama, ili o sumnji ili optužbi zbog kažnjivog djela.“

132 USRH, U-I-818/2015 od 14. prosinca 2016.

133 USRH, U-I-1380/2014, op. cit.

134 USRH, U-I-4536/2012, op. cit.

135 USRH, U-I-2822/2010 od 17. prosinca 2013. 
poslovne sposobnosti, centar je i dalje dužan brinuti o pravima i interesima osobe s duševnom smetnjom. ${ }^{136}$

Do povrede prava na pravično suđenje doći će i u slučaju da se odluka o ograničenju ili oduzimanju poslovne sposobnosti temelji na manjkavom psihijatrijskom vještačenju. Neprihvatljiva su vještačenja provedena isključivo na činjenicama iz spisa ili liječničke dokumentacije, a bez prethodnog pregleda osobe $\mathrm{s}$ duševnom smetnjom. ${ }^{137}$ Vještačenje u postupku ograničenja poslovne sposobnosti pacijenata ne bi trebali obavljati njihovi liječnici psihijatri zbog nespojivosti uloga liječnika i vještaka i mogućih sukoba interesa. ${ }^{138}$ Isto tako, odluke o stavljanju osobe pod skrbništvo ne smiju se jedino i isključivo donositi na temelju mišljenja i nalaza vještaka psihijatra. Da bi postupak bio pravičan, sud je dužan ispitati svjedoke i provesti druge dokaze. ${ }^{139}$ Formalna, petominutna ili desetominutna ročišta nikako ne mogu zadovoljiti ovaj proceduralni zahtjev. ${ }^{140}$ Pravo na pravično suđenje bit će povrijeđeno i ako se tijekom postupka osobi s duševnom smetnjom ne dostavljaju podnesci uključujući i odluku o oduzimanju poslovne sposobnosti. ${ }^{141}$ Kako bi institut skrbništva bio u skladu s ustavnopravnim standardima, država je dužna osigurati priznavanje različitih pravnih učinaka ovisno o tomu je li osobi samo djelomično ograničena ili u potpunosti oduzeta poslovna sposobnost. ${ }^{142}$ Jednom, nakon što je osoba stavljena pod skrbništvo, država ima i pozitivne obveze osigurati pravne mehanizme za redovite, periodične provjere uvjeta za povrat poslovne sposobnosti. ${ }^{143}$ Svi prethodno navedeni standardi u postupcima ograničenja poslovne sposobnosti ukazuju na zaključak kako naše ustavno sudište, kada raspravlja o mogućim povredama prava na pravično suđenje, razmatra pozicije stranaka u odnosu na predlaganje i izvođenje dokaza, ali i pravičnost postupka u cjelini.

\subsubsection{Ograničenje prava neubrojivim osobama}

U predmetima u kojima je ocjenjivao ustavnost ograničenja ili uskrate prava neubrojivim osobama, Ustavni sud se fokusirao na moguće povrede prava na pravično suđenje i prava na osobnu slobodu i sigurnost te jednakost svih pred zakonom. Budući da se prisilnom hospitalizacijom neubrojive osobe lišavaju slobode, postavilo se

136 USRH, U-I-4536/2012, ibid.

137 ESLJP, M.S. protiv Republike Hrvatske, zahtjev br. 36337/10 op. cit.

138 USRH, U-I-4536/2012, op. cit.

139 ESLJP, A.N. protiv Litve, op. cit.

140 ESLJP, Shtukaturov protiv Rusije, zahtjev br. 44009/05 op. cit.

141 ESLJP, Xi Y protiv Republike Hrvatske, zahtjev br. 5193/09 od 3. studenog 2011.; Knol Radoja, K.: Povreda procesnih prava osoba s invaliditetom, Zbornik Pravnog fakulteta u Zagrebu, vol. 65, br. 6, 2015., str. 942.

142 Prema trenutno važećim pravnim rješenjima u Obiteljskom zakonu (NN 103/2015.), gore navedeni ustavnopravni standard je ispunjen. Čl. 234., st. 2. Obiteljskog zakona zabranjuje da se punoljetne osobe potpuno liše poslovne sposobnosti. Pravna odredba u skladu je s poimanjem skrbništva koje u hrvatski pravni prostor unosi Konvencija o pravima osoba $\mathrm{s}$ invaliditetom i njezin Fakultativni protokol (NN - MU 6/2007., 3/2008., 5/2008.). O poslovnoj sposobnosti i ovoj Konvenciji vidi u: Weller, P.: Reconsidering legal capacity: radical critiques, governmentality and dividing practice, Griffith Law Review, vol. 23, br. 3, str. 502.-503.

143 ESLJP, Stanev protiv Bugarske, op. cit. 
pitanje može li se prisilni smještaj izjednačiti s kaznom zatvora, i ako da, treba li vrijeme koje je neubrojiva osoba provela u pritvoru/istražnom zatvoru uračunati u rok trajanja prisilnog smještaja. Ustavni sud je zaključio kako zakon ne daje mogućnost uračunavanja lišenja slobode tijekom kaznenog postupka u vrijeme određivanja prisilnog smještaja jer prisilni smještaj nije kaznenopravna sankcija. Drugim riječima, izostanak zakonske odredbe o ovoj mogućnosti samo po sebi dovoljno je da se zaključi kako podnositelj ustavne tužbe nije doveden u neravnopravan položaj u odnosu na zdrave optuženike. ${ }^{144}$ Izneseno obrazloženje suda samo je formalno razrješenje odnosa prisilne hospitalizacije neubrojivih i uračunavanja lišenja slobode tijekom kaznenog postupka u kaznenu sankciju. Naime, u obrazloženju je izostala sadržajna analiza prirode ovih instituta. Iako oba instituta dijele poveznicu oduzimanja prava na slobodu i osobnu sigurnost, svrha prisilne hospitalizacije neubrojivih jeste otklanjanje opasnosti od počinjenja kaznenog djela psihijatrijskim liječenjem, ${ }^{145}$ a kažnjavanja izricanje prijekora krivom počinitelju kako bi se postigla specijalna i generalna prevencija. ${ }^{146}$ Razlika između otklanjanja opasnosti i kažnjavanja bitna je razlika, pa je nadasve irelevantno da se opasnost neubrojivog okrivljenika inicijalno utvrđuje u kaznenom postupku prema stupnju vjerojatnosti saznanja o drugim relevantnim činjenicama. ${ }^{147}$ Jednom kada se isključe uvjeti za prisilnu hospitalizaciju neubrojive osobe ili istekne kazna zatvora krivom počinitelju, obje se osobe moraju otpustiti iz psihijatrijske, odnosno penalne ustanove. Prebacivanje osoba iz penalnog u medicinski sustav i obrnuto bez ispunjenja konkretnih zakonskih uvjeta protivno je njihovim temeljnim ljudskim pravima i stoga protuustavno. ${ }^{148}$ Različiti položaj neubrojivih osoba i krivih zatvorenika u skladu je s načelom jednakosti svih pred zakonom, jer ono ne zahtijeva da se sa svim građanima jednako postupa već da je učinjena razlika važna za postizanje svrhe različitoga postupanja. ${ }^{149}$

Kao i pri ocjeni pravičnosti postupka imenovanja skrbnika, i u postupcima određivanja ili produženja prisilnog smještaja osobama koje su ostvarile protupravno

144 USRH, U-I-54011/2009 od 9. prosinca 2009.

145 Prema čl. 44. ZZODS/97 neubrojivu osobu moglo se prisilno smjestiti u psihijatrijsku ustanovu ako je ustanovljeno da osoba pati od duševne smetnje i da postoji visoki stupanj vjerojatnosti da bi ta osoba zbog duševnih smetnji, zbog kojih je nastupila njezina neubrojivost, mogla ponovno počiniti kazneno djelo za koje je zaprijećena kazna zatvora u trajanju od najmanje tri godine. Sadašnji ZZODS/14 propisuje ponešto izmijenjene uvjete za prisilno hospitaliziranje neubrojive osobe. Prema čl. 51., st. 1., prisilno se mogu hospitalizirati samo neubrojive osobe s težom duševnom smetnjom zbog koje postoji vjerojatnost počinjenja težeg kaznenog djela, a za otklanjanje te opasnosti potrebno je liječiti ih u psihijatrijskoj ustanovi.

146 Čl. 41. Kaznenog zakona, NN 125/2011., 144/2012., 56/2015., 61/2015., 101/2017.

$147 \mathrm{Na}$ povezanost kriterija dokazivanja koji se primjenjuju u kaznenom postupku i u postupku prisilne hospitalizacije još je upozorio Vrhovni sud SAD-a u predmetu Minnesota ex rel. Pearson v. Probate Court, no ovakva spona nije poslužila kao razlog izjednačavanja kažnjavanja i prisilnog liječenja okrivljenika. Razlozi koji su doveli do ovakvog raspleta uočene kontroverze leže u različitim ovlastima države. Naime, u postupcima prisilnog smještaja neubrojivih okrivljenika država u velikoj mjeri primjenjuje svoje parens patriae ovlasti štiteći ih i skrbeći o njima. S druge strane, kazneni postupci provode se kako bi država osigurala javnu sigurnost. [Izdvojeno suprotno mišljenje suca Kennedya u Terry Foucha v. Louisiana, 504 U.S. 71 (1992)] 148 ESLJP, G. protiv Francuske, zahtjev br. 27244/09 od 23. veljače 2012.; Vitek v. Jones, op. cit. 149 Baxstrom v. Herald, 383 U.S. 107 (1966). 
djelo sud je preispitao i položaje stranaka pri provođenju dokaza i pravičnost postupka u njegovoj ukupnosti. Primjerice, u predmetu iz 2014. godine ustavno sudište je upozorilo kako propusti i nepravilnosti u vještačenju opasnosti neubrojive osobe mogu poljuljati jednakost oružja i dovesti do nepravičnog postupka. Takav disbalans postoji ako vještačenje provede psihijatar koji je istodobno zadužen i za liječenje neubrojive osobe, a ne postoje prihvatljivi razlozi i druge objektivne okolnosti koji bi opravdali ovakvu kumulaciju uloga. Uočena inicijalna povreda može prerasti u arbitrarni postupak ako nadležni sud donese odluku o prisilnom smještaju neubrojive osobe ponajprije na temelju spornog vještačenja. ${ }^{150}$ Sasvim suprotan zaključak Ustavni sud je donio ispitujući predmet iz 2014. godine u kojem je ustanovljeno da je odjelna liječnica koja je predložila produženje prisilnog smještaja svog neubrojivog pacijenta u ranijem kaznenom postupku sastavila nalaz i mišljenje na temelju kojeg ga je kazneni sud proglasio neubrojivim. ${ }^{151}$ Iako je kazneni postupak zaseban postupak u odnosu na postupak produženja prisilnog smještaja, posljedice po pravičnost postupka zbog sažimanja uloga vještaka i odjelnog liječnika u jednoj osobi u mnogome se ne razlikuju, posebice u odnosu na zahtjev da se sudski postupak mora provesti u skladu s vladavinom prava.

Određena odstupanja u standardima ustavnopravne zaštite neubrojivih osoba uočena su i u predmetima u kojima je sud raspravljao o proceduralnim garancijama prava na osobnu slobodu. Ispostavilo se kako jedno te isto pravno pitanje može dovesti do u potpunosti oprečnih zaključaka ako se ono razmatra u okvirima prava na pravično suđenje odnosno prava na slobodu. Naime, u predmetu U-III-1048/2015 čuvar je Ustava upozorio kako samo formalno postavljanje odvjetnika ne može pružiti neubrojivoj osobi adekvatnu pravnu pomoć u postupku prisilnog smještaja. ${ }^{152}$ Pasivnost odvjetnika i suda koji nije korigirao propuste u pravnom zastupanju mogu dovesti do povrede na slobodu u proceduralnom smislu. ${ }^{153}$ Ova je povreda toliko teška da nema

150 Navedeni predmet jedan je od rijetkih slučajeva u kojem se nadležno tijelo upustilo u ocjenu ustavnosti kvalitete vještačenja. Naime, Ustavni sud je prihvatio navode odvjetnika neubrojive osobe kako predmetno vještačenje ne pati samo od proceduralnih već i sadržajnih nedostataka. Ispostavilo se kako je zaključak o tomu da neubrojivi podnositelj boluje od paranoidne shizofrenije postavljen paušalno, bez objektivnih kriterija i suprotno pravilima struke. (USRH, U-I-726/2014 od 3. srpnja 2014.) No, analiza je pokazala kako u većini drugih predmeta ustavno sudište samo citira dijelove nalaza i mišljenja vještaka i pritom ne čini nikakvu analizu. Primjerice, iako je opasnost neubrojive osobe ključan uvjet za izricanje prisilnog smještaja, činjenica da se u vještačkom nalazu i mišljenju samo navodi kako opasnost postoji bez ikakvog daljnjeg objašnjenja nije pobudila sumnju ustavnog sudišta u valjanost vještačenja kao dokaza i mogućeg uzroka nepravičnog suđenja. (USRH, U-I-294/2015 od 3. lipnja 2015.) Isto tako ustavno sudište nije podvrglo kritici nalaz i mišljenje vještaka psihijatra u kojem se većinom citiraju odredbe ZZODS-a i navode elementi psihičkog stanja neubrojivog pacijenta bez ikakve podrobnije analize (USRH, U-I-1048/2015 od 15. prosinca 2015.).

151 USRH, U-I-4498/2015 od 11. lipnja 2014. Povreda će izostati i u onom slučaju kada se rješenje o upućivanju neubrojive osobe u psihijatrijsku ustanovu temelji na vještačenju provedenom $u$ prethodnom kaznenom postupku (USRH, U-III-1382/2016 od 20. travnja 2016.).

152 USRH, U-I-1048/2015, op. cit.

153 Bit prava na odvjetnika leži u zahtjevu da ,pojedinac koji je prisilno zadržan u psihijatrijskoj ustanovi zbog svog psihičkog stanja treba, osim ako ne postoje posebne okolnosti, dobiti učinkovito pravno zastupanje, a koje su nadležni sudovi dužni s pojačanom dužnošću nadzirati“ 
potrebe ispitivati je li prisilni smještaj prihvatliiva razmjerna mjera u materijalnim aspektima ograničenja osobne slobode. ${ }^{154} \mathrm{~S}$ druge strane, prigovori neubrojive osobe kako joj nije osigurano pravično suđenje zbog pasivnosti odvjetnika po službenoj dužnosti Ustavni sud ne smatra opravdanim, iako se zastupanje svelo na sudjelovanje na jednoj sudskoj raspravi i zaprimanje rješenja o prisilnom smještaju. Mišljenje je suda kako „... odluka punomoćnika o tome kako će zastupati svog branjenika ovisi o njegovoj slobodnoj procjeni, ovisno od konkretne pravne situacije“, što bi značilo da neaktivnost odvjetnika spada u taktiku zastupanja i ne može dovesti do povrede prava iz članka 29., stavak 1. Ustava. ${ }^{155}$

Osim gore navedenih suštinskih nedostataka, $\mathrm{u}$ analiziranim predmetima uočeni su i određeni propusti vezani za obrazlaganje (ne)postojanja povrede prava prisilno hospitaliziranih neubrojivih osoba. Iako se prigovori podnositelja ustavnih tužbi odnose na različita pravna pitanja (pasivnost odvjetnika, suda, kvalitetu vještačenja, utemeljenost oduzimanja slobode, produljenje pritvora, neuračunavanje istražnog zatvora u vrijeme trajanja prisilnog smještaja, povredu načela ne bis in idem), odluke se obrazlažu vrlo slično. U nekim predmetima citiraju se identični slučajevi ESLJP-a, unatoč tomu što citirana mišljenja iz tih predmeta nisu relevantna za konkretan predmet pred Ustavnim sudom. Zbog gotovo identičnog obrazlaganja mjerodavnog prava i mjerodavne sudske prakse, u različitim odlukama uočavaju se istovjetni dijelovi teksta. ${ }^{156}$ Određenu slabost predstavljaju i nedovoljno analitički koncipirane odluke u kojima se teško oteti dojmu da je Ustavni sud donio pravorijek na prečac, gotovo u žurbi, bez potrebne analize koju predmeti u kojima se raspravlja o mogućim ograničenjima prava na osobnu slobodu i pravično suđenje zahtijevaju. ${ }^{157}$ Takav

jer u suprotnome dolazi do povrede „... čl. 5., st. 1., toč. e) EK“. USRH, U-III-1190/2016 od 29. lipnja 2016.

154 USRH, U-I-1048/2015, op. cit. Vođenje postupka o prisilnom smještaju u odsutnosti neubrojive osobe još je jedna procesna povreda prava na slobodu zbog koje nije potrebno provoditi daljnja preispitivanja materijalnih zahtjeva produljenja prisilnog smještaja. (USRH, U-III-1048/2015, op. cit.) Identičan zaključak treba donijeti kada se obrazloženje rješenje o produljenju prisilnog smještaja u cijelosti zasniva na sadržaju prijedloga, a doneseno je na temelju vještačenja koja su obavljena prije četiri odnosno sedam godina (USRH, U-III-3797/2015 od 4. veljače 2016.;).

155 USRH, U-I-294/2015, op. cit.

156 USRH, U-III-1382/2016, op. cit.; USRH, U-III-2887/2016. od 29. lipnja 2016.; USRH, U-I726/2014, op. cit.; USRH, U-I-1048/2015, op. cit.; USRH, U-III-3797/2015, op. cit.; USRH, U-III-1190/2016, op. cit.

157 U predmetu U-III-1977/2016 Ustavni sud je donio odluku kojom se ustavna tužba odbija zbog toga što je, prema njegovom sudu, činjenično stanje u osporenom rješenju o produljenju prisilnog smještaja u potpunosti utvrđeno. Navedeni zaključak nije obrazložen analizom činjenica iz predmeta već konstatacijom da su „na ročištu... na kojem se odlučivalo o produljenju prisilnog smještaja... nazočili podnositelj, njegovi roditelji i punomoćnik, kao i voditeljica ustanove gdje je podnositelj prisilno smješten." (USRH, U-III-1977/2016 od 10. svibnja 2016.). U drugom slučaju Ustavni je sud ispitivanje slobode sveo na čisto proceduralna pitanja i zaključio kako „su o ograničenju slobode podnositeljice odlučivali nadležni sudovi u skladu s mjerodavnim odredbama ZKP-a, te stoga podnositeljici“" nije povrijeđeno pravo na osobnu slobodu i sigurnost (USRH, U-III - 1677/2009 od 22. travnja 2009.). U predmetu U-III-2887/2016 obrazloženje o primjeni mjerodavnih ustavnih načela na konkretan slučaj svelo se na šturo prepričavanje činjenica da je nadležni županijski sud utvrdio opasnost i razmotrio eventualno liječenje na 
je pristup parcijalan i lišen kreativnog sudskog aktivizma, zbog čega se rješavanje ustavnih tužbi neubrojivih osoba može svesti na puko formalističko sagledavanje njihovih prigovora. Ovakav ishod može oslabiti standarde ustavnopravne zaštite osoba s duševnim smetnjama što je u konačnici krajnje neprihvatljivo.

\subsubsection{Ostala prava osoba s duševnim smetnjama}

Osim ustavnosti ograničenja prethodno analiziranih prava, Ustavni sud se posebno bavio i zaštitom imovinskih prava osoba s duševnim smetnjama, kao i njihovim roditeljskim pravima te pravnim položajem djece s psihičkim teškoćama. $U$ predmetnim slučajevima, sud je primijenio načelo ograničenog preispitivanja mogućih povreda prava i upozorio kako je njegova primarna zadaća preispitati jesu li nadležna tijela državne i javne vlasti, rješavajući pojedine slučajeve, tumačila pravo u skladu s Ustavom. Drugim riječima, Ustavni sud nije neko novo sudsko tijelo koje ponovno preispituje činjenice i pravnu pozadinu slučaja već čuvar Ustava koji će razmatrati činjenice i pravo samo u onoj mjeri koliko je potrebno za donošenje zaključka o ustavnosti ograničenja prava osobe s psihičkim problemima.

U skladu s navedenim, ustavno sudište je zaključilo kako nasljednica koja boluje od shizofrenije i koja zbog te bolesti ne može pravilno percipirati i procijeniti realnost ne može dati valjanu izjavu o odricanja od nasljedstva, jer se zbog duševne smetnje nalazi u zabludi. ${ }^{158}$ Isto tako, kupoprodajni ugovor nekretnina koji su tužitelji sklopili iskoristivši zdravstveno stanje osobe za koju znaju da boluje od paranoidne psihoze, ništavan je i na ovakav zaključak ne utječe činjenica da je osobi s duševnom smetnjom tek nakon sklapanja ovog ugovora oduzeta poslovna sposobnost. ${ }^{159} \mathrm{~S}$ druge strane, ako je razvrgnuće suvlasničke zajednice nad stanom u interesu osobe s duševnom smetnjom jer je postignuta cijena u upravnom postupku veća od procijenjene vrijednosti njezina suvlasničkog dijela, odluka nadležnog upravnog tijela nije arbitrarni akt te nije došlo do povrede prava na pravično suđenje. ${ }^{160}$ Djeca s tjelesnim i duševnim oštećenjima imaju pravo na posebnu skrb i njegu koju im u prvom redu pružaju roditelji uz pomoć države. Naime, država je dužna ispuniti svoju pozitivnu obvezu osiguravanja uvjeta u društvu koji će omogućiti roditeljima da skrbe o svojoj djeci s duševnim smetnjama. ${ }^{161} \mathrm{U}$ predmetima u kojima se raspravlja o roditeljskim pravima osoba s duševnim smetnjama, odluku o povjeravanju djeteta potrebno je donijeti primjenom testa balansiranja ispitujući interese roditelja i interese djeteta, a pritom posebnu pozornost treba posvetiti najboljem interesu djeteta koji, ovisno o prirodi i ozbiljnosti pravnog pitanja, može odnijeti prevagu nad interesima roditelja. ${ }^{162}$

slobodi, a takvu je odluku prihvatio nadležan drugostupanjski sud (USRH, U-III-2887/2016., op. cit.).

158 USRH, U-III-911/2010 od 25. travnja 2013.

159 USRH, U-III-4217/2007 od 11. ožujka 2010.

160 USRH, U-III-1040/2012 od 13. studenog 2014.

161 USRH, U-II-1993/2001 od 20. veljače 2002.

162 USRH, U-II-1448/2014 od 1. lipnja 2016. Istaknuto stajalište u skladu je s praksom ESLJP-a, E.P. protiv Italije, zahtjev br. $31127 / 96$ od 16. studenog 1999.; ESLJP, K. i T. protiv Finske, zahtjev br. 25702/94 od 12. srpnja 2001.; ESLJP, Kocherov i Sergeyeva protiv Rusije, zahtjev br. 16899/13 od 29. ožujka 2016. 


\subsubsection{Status ranjive osobe i ustavnopravni standardi zaštite prava}

Raspravljajući o pravima osoba s duševnim smetnjama i ustavnosti njihovih ograničenja, Ustavni sud je više puta napomenuo kako se one smatraju ranjivom skupinom građana. ${ }^{163}$ Takav je stav zauzeo u kontekstu pojašnjenja proceduralnih garancija prava na slobodu i osobnu sigurnost iz članka 5., stavak 1., točka e) EK-a navodeći kako postupak prisilne hospitalizacije „,mora nužno pružiti jasna i učinkovita jamstva protiv proizvoljnosti“, pa se pritom trebaju iznijeti „vrlo važni razlozi kojima se opravdava svako ograničenje prava na slobodu“. No, što su to nužna i učinkovita jamstva i vrlo važni razlozi, odnosno kako se ranjivost kao ustavnopravni pojam može odraziti na odabir standarda procjene zaštite prava i sloboda psihijatrijskih pacijenta, ustavno sudište nije razotkrilo. Dok se naš procjenjivač ustavnosti zadovoljava samo formalnom naznakom ranjivosti u rješavanju predmeta, u praksi ESLJP-a i Vrhovnog suda SAD-a zauzeti su jasni stavovi o ovom ustavnopravnom pojmu i njegovom učinku.

U svojoj već bogatoj praksi, ESLJP je izgradio institut ranjivosti promišljajući o samim osnovama ljudskih prava i dužnosti društva da zaštiti najslabije članove zajednice. Naime, nakon usvajanja liberalnih koncepcija o ljudskim pravima i slobodama koje se zasnivaju na njihovoj univerzalnosti, odnosno tvrdnji da svi građani uživaju temeljna prava i slobode, ESLJP je počeo razvijati koncept ranjivosti kao pojam koji se vezuje uz određenog podnositelja zahtjeva, a proizlazi iz njegovih osobnih karakteristika odnosno iz okolnosti situacije u kojoj se našao. Ranjivost može biti inherentna pa su tako ranjiva djeca ${ }^{164} \mathrm{i}$ osobe s duševnim smetnjama. ${ }^{165}$ Ranjivost može nastati i zbog vanjskih okolnosti pa se ranjivima smatraju zatvorenici jer se tijekom izdržavanja kazne zatvora nalaze u vlasti države. Ako se kumulativno ostvare i osobne i vanjske okolnosti ranjivosti, stupanj vulnerabilnosti se povećava pa se podnositelj zahtjeva smatra posebno ranjivom osobom. ${ }^{166}$ Višestruka ranjivost stoga postoji kod zatvorenika s duševnim smetnjama, ${ }^{167}$ psihijatrijskih pacijenata koje je policija lišila slobode ${ }^{168}$ ili djece s psihičkim teškoćama koju su policijski djelatnici lišili slobode u početnoj fazi istrage. ${ }^{169}$

163 USRH, U-I-1048/2015, op. cit.; USRH, U-III-3797/2015, op. cit.; USRH, U-III-1382/2016, op. cit.; USRH, U-III-1190/2016, op. cit.; USRH, U-III-2887/2016., op. cit.

164 Suprotno izdvojeno mišljenje sudaca Pettiti i De Meyer u predmetu ESLJP, Nielsen protiv Danske, zahtjev br. 10929/84 od 28. studenog 1988. Djelomice suprotno izdvojeno mišljenje suca Bonella u predmetu ESLJP, E.P. protiv Italije, op. cit.; ESLJP, A.M.M. protiv Rumunjske, zahtjev br. 2151/10 od 14. veljače 2012.

165 ESLJP, A.N. protiv Litve, op. cit.

166 Timmer, A.: A Quiet Revolution: Vulnerability in the European Court of Human Rights, objavljeno u: Albertson Fineman, M. i Grear, A. (ur.): Vulnerability Reflections on a New Ethical Foundation for Law and Politics, Ashgate, 2013., str. 161.-162.

167 ESLJP, Paul i Audrey Edwards protiv Ujedinjenog Kraljevstva, zahtjev br. 46477/99 od 14. ožujka 2002.; ESLJP, Tokić i drugi protiv Bosne i Hercegovine, zahtjev br. 12455/04, 14140/05, 12906/06 i 26028/06 od 8. srpnja 2008.; ESLJP, Halilović protiv Bosne i Hercegovine, zahtjev br. 23968/05 od 24. studenog 2009.; Zatvorenike s duševnim smetnjama Vrhovni sud SAD-a naziva potrebitim zatvorenicima (eng. indigent prisoners) (Vitek v. Jones, op. cit.).

168 ESLJP, Saoud protiv Francuske, zahtjev br. 9375/02 od 9. listopada 2007.

169 ESLJP, Blokhin protiv Rusije, zahtjev br. 47152/06 od 14. studenog 2013. 
Ranjivost kao ustavnopravni konstrukt ima dalekosežne učinke koji se odražavaju na pooštravanje proceduralnih i materijalno-pravnih garancija zaštite prava i sloboda. Stručnjaci upozoravaju kako je dosadašnja analiza postupanja ESLJP-a pokazala kako on daje prednost $\mathrm{u}$ razmatranju zahtjevima koje podnose ranjive osobe (tzv. proceduralni prioritet). Jednom kada se pokrene postupak, ESLJP ocjenjuje moguće povrede prava i sloboda ranjivih osoba primjenom pojačanih ustavnopravnih testova (tzv. materijalni prioritet).${ }^{170}$ Primjerice, u predmetima u kojima se procjenjuju povrede prava iz članka 3. EK-a, razina težine povrede potrebne za donošenje zaključka kako se neko ponašanje smatra mučenjem, nečovječnim ili ponižavajućim ponašanjem bit će niža. ${ }^{171} \mathrm{U}$ predmetima u kojima se primjenjuje načelo razmjernosti, ranjivost se treba uzeti u obzir pri primjeni testa balansiranja, a država pritom ima široku slobodnu procjenu. ${ }^{172}$ Iako će konkretan učinak utjecaja ranjivosti na vaganje interesa države i ranjive osobe ovisiti o okolnostima pojedinog slučaja, jasno je da država neće uspjeti ispuniti test balansiranja ako se kod primjene mjera kojima se ograničavaju prava podnositelja uopće nije vodilo računa o njihovoj ranjivosti. Bilo koje ograničenje prava posebno ranjivih osoba treba se ispitati primjenom testa striktne skrutine (eng. the strict scrutiny test), a država će zadovoljiti ovaj test jedino ako dokaže da postoje bitni razlozi koji opravdavaju predmetno ograničenje. ${ }^{173}$ Isto tako, ranjivost utječe i na prirodu pozitivnih obveza koje država ima prema ranjivima. Kako bi se ispravila početna nejednakost onih koji su stigmatizirani i gurnuti na margine društva, država mora pojačano štititi njihova prava i slobode donošenjem mjera s konkretnijim i dalekosežnijim učincima. ${ }^{174}$ Ranjivost se ovakvim ustavnopravnim pristupom koristi kako konstrukt (re)distributivne pravde kojim se pojačano štiti dostojanstvo depriviranih građana i nalaže provođenje osjetljivih socioekonomskih akcija.

Upravo zbog uloge i učinka ranjivosti u kontekstu (re)distributivne pravde, Vrhovni sud SAD-a u krajnje je restriktivnim slučajevima priznao status ranjivosti građanima o čijim se pravima odlučuje. Naime, u američkom kontekstu ranjivost je uzrokovana opetovanim diskriminiranjem, stigmatizacijom i deprivacijom prava pojedine skupine građana od većine, pa su shodno tome, primjer ranjive skupine afroamerički građani. ${ }^{175}$ Budući da se ova ranjiva skupina nije uspjela zaštititi od nepravednih postupaka većine, sasvim je legitimno pružiti im sudsku zaštitu, no ona je čisto proceduralne prirode. Zakonske odredbe izgrađene na temelju rasne diskriminacije mogu biti protivne načelu jednakosti svih pred zakonom iz četrnaestog

170 Timmer, A., op. cit., str. 163.-165.

171 ESLJP, Stawomir Musiat protiv Poljske, zahtjev br. 28300/06 od 20. siječnja 2009.

172 ESLJP, B. protiv Rumunjske br. 2, zahtjev br. 1285/03 od 19. veljače 2013.; ESLJP, Zehentner protiv Austrije, op. cit.

173 ESLJP, Z.H. protiv Mađarske, zahtjev br. 28973/11 od 8. studenog 2012.

174 Primjerice, u predmetu Storck protiv Njemačke, op. cit., ESLJP je zaključio kako je država nositelj pozitivnih obveza prema kojima mora učinkovito zaštititi ranjive psihijatrijske pacijente od oduzimanja slobode u privatnim klinikama. Isto tako, ranjivost prisilno hospitaliziranih pacijenata razlog je zbog kojeg teret dokazivanja učinkovitosti mjera protiv arbitrarnog oduzimanja slobode leži na državi (ESLJP, M. protiv Ukrajine, zahtjev br. 2452/04 od 19. travnja 2012.).

175 McCloskey, R., G.: The American Supreme Court: Fifth Edition, The University of Chicago Press, Chicago, London, 2010., str. 233. 
amandmana Ustava, pa su stoga podložne najstrožoj procjeni ustavnosti, odnosno testu striktne skrutine. ${ }^{176}$ Iznimno, prava ranjivih mogu se pojačano štititi afirmativnim akcijama, no i u tom slučaju njihov je cilj ukloniti posljedice diskriminacije uključivanjem ranjivih u društvo, a ne promicanjem (re)distributivne pravde. ${ }^{177}$

Sudsko razumijevanje ranjivosti odrazilo se i na stajališta o adekvatnoj zaštiti prava osoba s duševnim smetnjama. Osobe koje nose breme psihičke smetnje razlikuju se od drugih članova društva pa se ustavnost uskrate njihovih prava treba procjenjivati prema načelu jednakosti svih pred zakonom. U skladu s navedenim, za provođenje zakonskih ograničenja prava država mora imati legitiman interes. Zaštita i briga o građanima s psihičkim poteškoćama takav je jedan interes, no unatoč tomu ispostavilo se da su se i državni i federalni zakoni donosili uz prisutnost trajne antipatije ili predrasuda o ovim osobama. Uočena činjenica sama po sebi nije bila dovoljna da Vrhovni sud SAD-a proglasi osobe $\mathrm{s}$ duševnim smetnjama ranjivima i pokrene posebnu ustavnopravnu zaštitu. Iako „negativan pristup“ i „strahovi“ često dolaze u paketu s iracionalnim predrasudama, njihova prisutnost nije povreda Ustava. ${ }^{178}$ Osim toga, mišljenje je suda da unatoč psihičkim problemima, ovi građani mogu privući pozornost zakonodavca pa nisu bez političke moći. Stoga odgovarajući test za procjenu ustavnosti zakonskih odredbi kojima se uskraćuju prava osoba s duševnim smetnjama ne može biti test striktne skrutine. Rješenje je pronađeno u nešto blažem testu, testu pojačane skrutine (eng. heightened scrutiny) jer on daje dovoljno prostora državi da donosi poticajne mjere za ostvarivanje punog potencijala osoba s duševnim smetnjama, ali i mjere za ograničavanje njihovih prava. ${ }^{179}$

Istovjetan pristup Vrhovni sud SAD-a primijenio je i u predmetima u kojima se ocjenjivala ustavnost oduzimanja slobode pacijentima na prisilnom liječenju $u$ psihijatrijskim bolnicama. Neosporno je da država ima interes brinuti o građanima koji zbog svoje duševne smetnje ne mogu voditi brigu o sami sebi kao i interes zaštititi zajednicu od opasnih postupaka duševno bolesnih osoba. ${ }^{180}$ No, isto tako, priznaje se $\mathrm{i}$ interes pacijenata da im se neopravdano ne ograničava sloboda i da ih se ne izvrguje stigmatizaciji i ostalim negativnim posljedicama koje za sobom povlači prisilna hospitalizacija. ${ }^{181}$ Interes osoba s duševnim smetnjama je toliko velik da država mora osigurati posebne proceduralne garancije pravičnog suđenja iz četrnaestog amandmana u postupcima prisilnog smještaja. Zbog važnosti ovog interesa u potpunosti je neprihvatljiva primjena testa dokazivanja uvjeta za prisilnu hospitalizaciju prevagom dokaza (eng. preponderance of the evidence) koji se inače primjenjuje u građanskim parnicama. S druge strane test dokazivanja iznad razumne sumnje (eng. beyond a reasonable doubt) iz kaznenog postupka također je neadekvatan. Naime, takvim bi se

176 Fallon Jr., R., H.: The Dynamic Constitution, An Introduction to American Constitutional Law, Cambridge University Press, Cambridge, 2004., str. 111.

177 Sajó, A.: Victimhood and Vulnerability as Sources of Justice, objavljeno u: Kochenov, D., De Búrca, G. i Williams, A.: Europe's Justice Deficit?, Hart Publishing, Oxford, Portland, 2015., str. 348.

178 Bord of Trustees of Univ. of Ala. v. Garrett, 531 U.S. 356 (2001).

179 Cleburne v. Cleburne Living Ctr., op. cit.

180 O'Connor v. Donaldson, op. cit.

181 Chemerinsky, E., op. cit., str. 885.; Vitek v. Jones, op. cit.; Zinermon v. Burch, op. cit. 
testom postavila obveza državi da s velikom sigurnošću dokaže postojanje duševne smetnje koja se zbog nesigurnih psihijatrijskih dijagnoza u biti ne može ispuniti. Sumnju u ispravnost psihijatrijskih dijagnoza i zaključaka psihijatrije kao znanstvene discipline Vrhovni sud je izrekao u više presuda. ${ }^{182}$ Kriticizam suda proizlazi iz njegova dugogodišnjeg odbijanja da prihvati standarde koji se empirijski ne mogu identificirati. Nesigurnost psihijatrijskih zaključaka izravan je uzrok prihvaćanja srednjeg standarda zaštite slobode psihijatrijskih pacijenata. Država je naime dužna dokazati postojanje uvjeta za prisilnu hospitalizaciju testom jasnih i uvjerljivih dokaza (eng. clear and convincing evidence). ${ }^{183}$ Neovisno o prirodi prava o čijoj se ustavnosti raspravljalo, stav najvišeg sudišta SAD-a je jasan: osobe s duševnom smetnjom nisu ranjive osobe pa njihova prava zaslužuju srednju razinu ustavnopravne zaštite.

\section{ZAKLJUČNA RAZMATRANJA}

Zadnjih godina statistike duševnog zdravlja pokazuju kako modernim državama haraju pandemije duševnih smetnji. U vrtoglavom ritmu odvijanja svakodnevnice u kojoj je zatočen moderan čovjek, stres, nesigurnost i neizvjesnost duboko nagrizaju njegove urođene i stečene mehanizme očuvanja duševnog zdravlja. Stoga ne čudi da u takvim okolnostima duševno zdravlje postaje iznimno krhko, pa je tri puta veća vjerojatnost da će osoba oboljeti od duševne smetnje nego biti žrtvom prometne nesreće u Republici Hrvatskoj. ${ }^{184}$ Statistike su neumoljive i pozivaju na pojačanu zaštitu prava osoba s duševnim smetnjama putem izgrađenih mehanizama u pravnom sustavu. Pravni sustav nije neki izdvojeni, amorfni, paralelni sustav već krvožilno tkivo koje prožima sve sfere odvijanja društvenog života. Pružanje zaštite priznatih prava njegov je bitan sastavni dio koji se ostvaruje u profinjenoj ravnoteži zakonodavne i sudske aktivnosti. U situacijama u kojima dolazi do podbačaja zaštite prava u djelovanju ovih dvaju vlasti, ustavnopravna zaštita postaje ključni mehanizam rehabilitacije ustavnosti pojedinih zakonodavnih akata ili odluka tijela javne ili državne vlasti. Potreba za zaštitom postaje tim veća, ako se preispituje ustavnost ograničenja prava građana koji su historijski izolirani na marginama društva, odnosno fizički izdvojeni od ostatka građana u psihijatrijskim ili socijalnim ustanovama.

Unatoč potrebi za pojačanom zaštitom osoba s duševnim smetnjama, analiza cjelokupne prakse Ustavnog suda Republike Hrvatske pokazala je da se o njihovim pravima raspravlja iznimno, gotovo slučajno. Podatak da samo $3 \%$ predmeta od ukupnog broja odluka i rješenja otpada na predmete u kojima se preispitivala ustavnost položaja i ograničenja prava psihijatrijskih pacijenata zabrinjava, posebice ako se uzme u obzir da je naše najviše sudište više puta pokazalo nespremnost i pasivnost upustiti se u meritorno rješavanje predmeta iz uzorka. Naime, u nekoliko slučaja

182 Earl P. Greenwood v. United States of America, 350 U.S. 366 (1956); Teofilo Medina, Jr. v. California, 505 U.S. 437 (1992); Podudarno izdvojeno mišljenje sutkinje O’Connor i suprotno izdvojeno mišljenje suca Kennedya u predmetu Terry Foucha v. Louisiana, op. cit.

183 Addington v. Texas, op. cit.; Terry Foucha v. Louisiana, op. cit.

184 Prema službenim statistikama MUP-a u 2015. godini u Republici Hrvatskoj je 15372 osoba ozlijeđeno ili su izgubile život u prometnim nesrećama. Republika Hrvatska, Ministarstvo unutarnjih poslova: Bilten o sigurnosti cestovnog prometa 2015., Zagreb, 2016., str. 3. 
uočena je formalna pasivnost u prihvaćanju predmeta. Taktiku formalne pasivnosti sudište je razvilo na dvojak način. Puštanjem da protek vremena učini svoje i da sporne zakonske odredbe prestanu važiti, Ustavni sud je rješenjem odbacio prijedloge za pokretanje postupka za ocjenu suglasnosti s Ustavom. Isto tako, ustavno sudište je u nekoliko predmeta rješenjem odbacilo ustavne tužbe kao nedopuštene jer su ih podnijele osobe u potpunosti lišene poslovne sposobnosti bez odobrenja skrbnika. Ovi predmeti samo su formalno riješeni jer je u konačnici podnositeljima prijedloga i ustavnih tužbi odbijena ustavnopravna zaštita.

Sadržajna analiza predmeta iz uzorka pokazala je da se u nekim predmetima naziru sveprisutni tragovi materijalne pasivnosti. Iako se Ustavni sud upustio u rješavanje predmeta, takvo što je učinjeno bez konkretne, dubinske analize ograničenja prava podnositelja. Izostala je primjena odgovarajućih ustavnopravnih standarda, primjerice načela razmjernosti pri procjeni ograničenja prava na slobodu ili prava na privatnost i samoodređenje osobe s duševnom smetnjom. U nekim predmetima argumentacijski slijed se zasnivao samo na nijekanju argumenata koje je iznio podnositelj. Veliki je problem i prisutnost gotovo identičnih rečenica u obrazloženju pravorijeka koje se ponavljaju iz predmeta u predmet. Isto tako, uočeno je da se u nekim predmetima navodi pojam ranjivosti osoba s duševnim smetnjama, no pritom se jasno i precizno ne pojašnjava ustavnopravno značenje toga pojma niti njegov utjecaj na testove procjene ustavnosti ograničenja slobode i prava i pozitivne obveze države.

Sudska praksa ESLJP-a i Vrhovnog suda SAD-a pokazala je da ova sudišta nisu zauzela identične stavove o ranjivosti osoba s duševnim smetnjama. Dok je ranjivost svojevrsni spiritus movens u preraspodjeli (re)distributivne pravde $\mathrm{u}$ europskom kontekstu, najviše sudište SAD-a nije sklono prihvatiti ranjivost psihijatrijskih pacijenata već ustraje na testu pojačane skrutine odnosno testu jasnih i uvjerljivih dokaza za zaštitu njihovih prava. Razlika u stajalištima ovih sudišta dobar je pokazatelj da se u ustavnom pravu ne trebaju i ne smiju prihvaćati gotova rješenja iz komparativnog prava, jer s obzirom na svojevrsno obilje društvenih i osobnih okolnosti podnositelja, ona mogu biti u hrvatskim okvirima manjkava, neodgovarajuća te dovesti do podbačaja ustavnopravne zaštite. No, komparativni pravci zaštite prava osoba s psihičkim poteškoćama još su uvijek dobri pokazatelji globalnih stremljenja prema njihovom priznavanju i očuvanju. U trenutcima u kojima se inzistira na priznavanju različitosti osoba s duševnim smetnjama i svojevrsnoj prilagodbi društva kako bi se prihvatila ta različitost i osiguralo da su te osobe njegovi punopravni članovi, formalnoj i materijalnoj pasivnosti u rješavanju predmeta pri Ustavnom sudu nema mjesta. U protivnome, ostvareni stupanj ustavne zaštite bio bi još samo jedan od pokazatelja marginalizacije onih kojima je zbog psihičkih problema s kojima se svakoga dana hvataju ukoštac ovakva zaštita najpotrebnija. Kojim putem naše najviše sudište treba krenuti u zaštiti prava svih osoba s duševnim smetnjama dobro pokazuje njegova novija praksa u priznavanju prava osobama $\mathrm{s}$ ograničenom ili oduzetom poslovnom sposobnošću. U tim predmetima uočena je crta sudskog aktivizma u obrazlaganju zauzetih stajališta koja se razvila pod utjecajem strasbourške judikature. Naime, povod za podizanje kvalitete ustavnopravne zaštite osoba pod skrbništvom u biti je bio negativan budući da se radilo o predmetima koje 
je Republika Hrvatska izgubila pred ESLJP-om. Nakon gotovo tri desetljeća ustavne prakse i desetaka predmeta pred strasbourškim sudištem, vrijeme je da se u ustavnom sudovanju nastave razvijati uočeni aktivistički pravci i pruži punopravno priznanje prava osobama s duševnim smetnjama.

\section{LITERATURA}

1. Babić-Bosanac, S.: Zaštita prava na slobodu prisilno hospitaliziranih duševno oboljelih osoba pod okriljem članka 5. Europske konvencije o zaštiti ljudskih prava i temeljnih sloboda, Pravni vjesnik, vol. 25, br. 1, 2009., str. 41.-64.

2. Bačić, A.: Ustavne promjene i dileme konstitucionalizma, Zbornik radova Pravnog fakulteta u Splitu, vol. 46, br. 4, 2009., str. 649.-666.

3. Barak, A.: Proportionality, Constitutional Rights and their Limitations, Cambridge University Press, Cambridge, 2012.

4. Barić, S.: The Transformative Role of the Constitutional Court of the Republic of Croatia: From the ex-Yu to the EU, Analitika - Center for Social Research, Sarajevo, 2016., str. 6.-39.

5. Bartlett, P. i dr.: Mental Disability and the European Convention on Human Rights, Martinus Nijhoff Publishers, Leiden, Boston, 2007.

6. Bell, D.: What Is Liberalism?, Political Theory, 2014., vol. 42, br. 6, 2014., str. 682.-715.

7. Bloom, D. E. i dr.: The Global Economic Burden of Noncommunicable Diseases, World Economic Forum, Harvard School of Public Health, Geneva, 2011.

8. Center for Behavioral Health Statistics and Quality: Key Substance Use and Mental Health Indicators in the United States: Results from the 2015 National Survey on Drug Use and Health, Rockville, 2016.

9. Chemerinsky, E.: Constitutional Law, Aspen Law \& Business, Gaithersburg, New York, 2001.

10. Council of Europe: Convention for the Protection of Human Rights and Fundamental Freedoms and Protocol, objavljeno na: $<$ http://www.echr.coe.int/Documents/Collection Convention 1950_ENG.pdf>, zadnji put posjećeno 1. studenog 2017.

11. Diseth, R. R.: Compulsory Mental Health Care in Norway: A Study of the Interface between the Law and Psychiatry, Division of Mental Health and Addiction, Institute of Clinical Medicine, Faculty of Medicine, University of Oslo, Oslo, 2013.

12. Doak, D. D.: Theorizing Disability Discrimination in Civil Commitment, Texas Law Review, vol. 93, 2014.-2015., str. 1589.-1629.

13. Đurđević, Z.: Pravni okvir za primjenu prisilne hospitalizacije: regulativa i kritički osvrt, objavljeno u: Štrkalj-Ivezić, S. (ur.): Medicinski i pravni okvir za hospitalizaciju osoba $\mathrm{s}$ duševnim smetnjama, Smjernice za primjenu prisilne hospitalizacije u praksi, Hrvatski liječnički zbor, Udruga Svitanje, Zagreb, 2011., str. 9.-34.

14. ESLJP, A.M.M. protiv Rumunjske, zahtjev br. 2151/10 od 14. veljače 2012.; A.N. protiv Litve, zahtjev br. 17280/08 od 31. svibnja 2016.; Aerts protiv Belgije, zahtjev br. 25357/94 od 30. srpnja 1998.; B. protiv Rumunjske br. 2, zahtjev br. 1285/03 od 19. veljače 2013.; Blokhin protiv Rusije, zahtjev br. 47152/06 od 14. studenog 2013.; Centre for Legal Resources on Behalf of Valentin Câmpeanu protiv Rumunjske, zahtjev br. 47848/08 od 17. srpnja 2014.; E.P. protiv Italije, zahtjev br. $31127 / 96$ od 16. studenog 1999.; G. protiv Francuske, zahtjev br. 27244/09 od 23. veljače 2012.; H.L. protiv Ujedinjenog Kraljevstva, zahtjev br. 45508/99 od 5. listopada 2004.; Halilović protiv Bosne i Hercegovine, zahtjev br. 23968/05 od 24. studenog 2009.; Herczegfalvy protiv Austrije, zahtjev br. 10533/83 od 24. rujna 1992.; Hutchison Reid protiv Ujedinjenog Kraljevstva, zahtjev br. 50272/99 od 20. veljače 2003.; Ilievska protiv Bivše jugoslavenske Republike Makedonije, zahtjev br. 20136/11 od 7. svibnja 2015.; Johnson protiv Ujedinjenog Kraljevstva, zahtjev br. 
22520/93 od 24. listopada 1997.; K. i T. protiv Finske, zahtjev br. 25702/94 od 12. srpnja 2001.; Kocherov i Sergeyeva protiv Rusije, zahtjev br. 16899/13 od 29. ožujka 2016.; Kucheruk protiv Ukrajine, zahtjev br. 2570/04 od 6. rujna 2007.; L.B. protiv Belgije, zahtjev br. 22831/08 od 2. listopada 2012.; M. protiv Ukrajine, zahtjev br. 2452/04 od 19. travnja 2012.; M.S. protiv Republike Hrvatske br. 2., zahtjev br. 75450/12 od 19. veljače 2015.; M.S. protiv Ujedinjenog Kraljevstva, zahtjev br. 24527/08 od 3. svibnja 2012.; Matter protiv Slovačke, zahtjev br. 31534/96 od 5. srpnja 1999.; Nielsen protiv Danske, zahtjev br. 10929/84 od 28. studenog 1988.; Nowicka protiv Poljske, zahtjev br. 30218/96 od 3. prosinca 2002.; Paul i Audrey Edwards protiv Ujedinjenog Kraljevstva, zahtjev br. 46477/99 od 14. ožujka 2002.; Plesó protiv Mađarske, zahtjev br. 41242/08 od 2. listopada 2012.; R.L. i M.-J.D. protiv Francuske, zahtjev br. 44568/98 od 19. svibnja 2004.; Romanov protiv Rusije, zahtjev br. 63993/00 od 20. listopada 2005.; Rupa protiv Rumunjske, zahtjev br. 58478/00 od 16. prosinca 2008.; Saoud protiv Francuske, zahtjev br. 9375/02 od 9. listopada 2007.; Shopov protiv Bugarske, zahtjev br. 11373/04 od 2. rujna 2010.; Shtukaturov protiv Rusije, zahtjev br. 44009/05 od 27. lipnja 2008.; Stawomir Musiat protiv Poljske, zahtjev br. 28300/06 od 20. siječnja 2009.; Stanev protiv Bugarske, zahtjev br. 36760/06 od 17. siječnja 2012.; Storck protiv Njemačke, zahtjev br. 61603/00 od 16. lipnja 2005.; Tokić i drugi protiv Bosne i Hercegovine, zahtjev br. 12455/04, 14140/05, 12906/06 i 26028/06 od 8. srpnja 2008.; V. protiv Ujedinjenog Kraljevstva [GC], zahtjev br. 24888/94 od 16. prosinca 1999.; V.D. protiv Republike Hrvatske, zahtjev br. 15526/10 od 8. studenog 2011.; Varbanov protiv Bugarske, zahtjev br. 31365/96 od 5. listopada 2000.; Winterwerp protiv Nizozemske, zahtjev br. 6301/73 od 24. listopada 1979.; X i Y protiv Nizozemske, zahtjev br. 8978/80 od 26. ožujka 1985.; X i Y protiv Republike Hrvatske, zahtjev br. 5193/09 od 3. studenog 2011.; X. protiv Finske, zahtjev br. 34806/04 od 3. srpnja 2012.; Z.H. protiv Mađarske, zahtjev br. 28973/11 od 8. studenog 2012. te Zehentner protiv Austrije, zahtjev br. 20082/02 od 16. srpnja 2009.

15. Eurostat: Mental Health and Related Issues Statistics, objavljeno na: $<$ http://ec.europa. eu/eurostat/statistics-explained/index.php/Mental_health_and_related_issues_statistics>, zadnji put posjećeno 1. studenog 2017.

16. Fallon Jr., R. H.: The Dynamic Constitution, An Introduction to American Constitutional Law, Cambridge University Press, Cambridge, 2004.

17. Flynn, E. i Arstein-Kerslake, A.: The Support Model of Legal Capacity: Fact, Fiction, or Fantasy?, Berkeley Journal of International Law, vol. 32, br. 1, 2014., str. 124.-143.

18. Galligan, D. J. i Versteeg, M.: Theoretical Perspectives on the Social and Political Foundations of Constitutions, objavljeno u: Galligan, D. J. i Versteeg, M. (ur.): Social and Political Foundations of Constitutions, Cambridge University Press, Cambridge, 2015., str. 3.-48.

19. Goreta, M. i dr. Indikacije za forenzični tretman smanjeno ubrojivih i neubrojivih počinitelja kaznenih djela (1998-2002), Hrvatski ljetopis za kazneno pravo i praksu, vol. 14, br. 1, 2007., str. 15.-40.

20. Grozdanić, V., Tripalo, D.: Novosti u Zakonu o zaštiti osoba s duševnim smetnjama, Hrvatski ljetopis za kazneno pravo i praksu, vol. 20, br. 2, 2013., str. 795.-820.

21. Grozdanić, V.: Novi Zakon o zaštiti osoba s duševnim smetnjama - između zahtjeva konvencijskog prava i mogućnosti hrvatskog društva, objavljeno u: Grozdanić, V. (ur.): Komentar Zakona o zaštiti osoba s duševnim smetnjama s provedbenim propisima, međunarodnim dokumentima i presudama Europskog suda za ljudska prava, Pravni fakultet Sveučilišta u Rijeci, Rijeka, 2015., str. XIII.-XIX.

22. Gusy, C. i Müller, S.: The Protection of Marginalised Individuals and Minorities in Germany: The Role of National and European Judicial Mechanisms, objevljeno u: Anagnostou, D. i Psychogiopoulou, E. (ur.): The European Court of Human Rights and the Rights of Marginalised Individuals and Minorities in National Context, Martinus Nijhoff, Leiden, Boston, 2010., str. 91.-114. 
23. Hrvatski zavod za javno zdravstvo, Hrvatski zdravstveno-statistički ljetopis za 2005. i 2015. godinu, Zagreb, 2006., 2016.

24. Kazneni zakon, NN 125/2011., 144/2012., 56/2015., 61/2015., 101/2017.

25. Knol Radoja, K.: Povreda procesnih prava osoba s invaliditetom, Zbornik Pravnog fakulteta u Zagrebu, vol. 65, br. 6, 2015., str. 931.-954.

26. Konvencija o pravima osoba s invaliditetom i njezin Fakultativni protokol, NN-MU 6/2007., 3/2008., 5/2008.

27. Kopel, D. B. i Cramer, C. E.: Reforming Mental Health Law to Protect Public Safety and Help the Severely Mentally Ill, Howard Law Journal, vol. 58, br. 3, 2015., str. 715.-778.

28. Korać Graovac, A. i Čulo, A.: Konvencija o pravima osoba s invaliditetom - novi pristup shvaćanju prava osoba s duševnim smetnjama, Zbornik Pravnog fakulteta u Zagrebu, vol. 61, br. 1, 2011., str. 65.-109.

29. Krapac, D.: Postupak pred Ustavnim sudom Republike Hrvatske, Ustrojstvo i porceduralni elementi ustavnog nadzora, Narodne novine, Zagreb, 2014.

30. Levin, R.: Responsiveness to Difference: ADA Accommodations in the Course of an Arrest, Stanford Law Review, vol. 69, 2017., str. 269.-320.

31. McCloskey, R. G.: The American Supreme Court: Fifth Edition, The University of Chicago Press, Chicago, London, 2010.

32. McCure, J. A.: Psychiatric Boarding in New Hampshire: Violation of a Statutory Right to Treatment, University of New Hampshire Law Review, vol. 14, br. 1, 2015., str. 197.-226.

33. McHugh, J. T.: Idiots and Insane Persons: Electoral Exclusion and Democratic Values within the Ohio Constitution, Albany Law Review, vol. 76, br. 4, 2013., str. 2189.-2217.

34. Mental Disability Advocacy Center i Udruga za društvenu afirmaciju osoba s duševnim smetnjama (SJAJ): Daleko od očiju, Ljudska prava u psihijatrijskim bolnicama i ustanovama socijalne skrbi u Hrvatskoj, Budimpešta, Zagreb, 2011.

35. Obiteljski zakon, NN 103/2015.

36. Odluka njemačkog Ustavnog suda od 23. ožujka 2011. godine, 2 BvR 882/09.

37. Pecorini, M.: Trying to Fit a Square Peg into a Round Hole: Why Title II of the Americans with Disabilities Act Must Apply to All Law Enforcement Services, Journal of Law and Policy, vol. 24, br. 2, 2016., str. 551.-594.

38. Pinals, A. D. i Mossman, D.: Evaluation for Civil Commitment, Oxford University Press, Oxford, New York, 2012.

39. Raub, A. i dr.: Constitutional Rights of Persons with Disabilities: An Analysis of 193 National Constitutions, Harvard Human Rights Journal, vol. 29, 2016., str. 203.-240.

40. Republika Hrvatska, Pravobranitelj za osobe s invaliditetom: Izvješće o radu Pravobraniteljice za osobe s invaliditetom za 2016. godinu, Zagreb, 2017.

41. Republika Hrvatska, Pučki pravobranitelj: Izvješće o ljudskim pravima osoba s duševnim smetnjama u psihijatrijskim ustanovama u okviru djelovanja Nacionalnog preventivnog mehanizma u 2014. godini, Zagreb, 2015.

42. Ryan, T. i dr.: Voting with an 'Unsound Mind'? A Comparative Study of the Voting Rights of Persons with Mental Disabilities, UNSW Law Journal, The University of New South Wales Law Journal, 2016., vol. 9, br. 3, str. 1038.-1071.

43. Sajó, A.: Emotions in Constitutional Institutions, Emotion Review, vol. 8, br. 1, 2016. str. 44.-49.

44. Sajó, A.: Victimhood and Vulnerability as Sources of Justice, objavljeno u: Kochenov, D., De Búrca, G. i Williams, A.: Europe's Justice Deficit?, Hart Publishing, Oxford, Portland, 2015., str. 337.-348.

45. Simon, J. i Rosenbaum, S. A.: Dignifying Madness: Rethinking Commitment Law in an Age of Mass Incarceration, University of Miami Law Review, vol. 70, 2015.-2016., str. 1.-52.

46. Smerdel, B.: Ustavno uređenje europske Hrvatske, Narodne novine, Zagreb, 2013. 
47. Škorić, M. i Srdoč, E.: Pravni položaj neubrojivih počinitelja protupravnih djela u Republici Hrvatskoj, Zbornik radova Pravnog fakulteta u Splitu, god. 52, 4/2015., str. 933.-953.

48. Timmer, A.: A Quiet Revolution: Vulnerability in the European Court of Human Rights, objavljeno u: Albertson Fineman, M. i Grear, A. (ur.): Vulnerability Reflections on a New Ethical Foundation for Law and Politics, Ashgate, 2013., str. 147.-170.

49. UN-ov Odbor za prava osoba s invaliditetom: Zaključne primjedbe o Inicijalnom izvješću Hrvatske, CRPD/C/HRV/CO/1 od 17. travnja 2015.

50. USRH, U-I-1048/2015 od 15. prosinca 2015.; U-I-1380/2014 od 20. svibnja 2015.; U-I1525/2006 od 3. srpnja 2008.; U-I-1845/2006 od 15. studenog 2006.; U-I-2695/2012 i dr. od 28. rujna 2015.; U-I-2822/2010 od 17. prosinca 2013.; U-I-294/2015 od 3. lipnja 2015.; U-I-422/1999 od 13. listopada 1999.; U-I-4498/2015 od 11. lipnja 2014.; U-I4536/2012 od 14. siječnja 2016.; U-I-54011/2009 od 9. prosinca 2009.; U-I-677/2011 od 27. siječnja 2015.; U-I-726/2014 od 3. srpnja 2014.; U-I-796/2012 od 6. svibnja 2015.; U-I-818/2015 od 14. prosinca 2016.; U-II-1448/2014 od 1. lipnja 2016.; U-II1993/2001 od 20. veljače 2002.; U-III - 1677/2009 od 22. travnja 2009.; U-III-1040/2012 od 13. studenog 2014.; U-III-1190/2016 od 29. lipnja 2016.; U-III-1382/2016 od 20. travnja 2016.; U-III-1977/2016 od 10. svibnja 2016.; U-III-2040/2016 od 7. rujna 2016.; U-III-2040/2016 od 7. rujna 2016.; U-III-2887/2016. od 29. lipnja 2016.; U-III-3797/2015 od 4. veljače 2016.; U-III-4217/2007 od 11. ožujka 2010.; U-III-4700/2011 od 14. siječnja 2015.; U-III-4700/2011 od 14. siječnja 2015. te U-III-911/2010 od 25. travnja 2013.

51. Ustav Republike Hrvatske, NN 56/1990., 135/1997., 113/2000., 28/2001., 76/2010., $5 / 2014$.

52. Ustavni zakon o Ustavnom sudu Republike Hrvatske, NN 99/1999., 29/2002.

53. Vrhovni sud SAD-a, Addington v. Texas, 441 U.S. 418 (1979); Zinermon v. Burch, 494 U.S. 113 (1990); Baxstrom v. Herald, 383 U.S. 107 (1966); Bord of Trustees of Univ. of Ala. v. Garrett, 531 U.S. 356 (2001); City and County of San Francisco, California, et ll. v. Sheehan, 575 U.S. (2015); Cleburne v. Cleburne Living Ctr., 473 U.S. 432 (1985); Earl P. Greenwood v. United States of America, 350 U.S. 366 (1956); Humphrey v. Cady, 405 U.S. 504 (1972); Jackson v. Indiana, 435 U.S. 975, 98 S. Ct. 1623, 56 L. Ed. 2d 69 (1978); Jones v. United States, 463 U.S. 354 (1983); McCulloch v. Maryland, 17 U.S. 316 (1819); McNeil v. Patuxent Institution, 407 U.S. 245 (1972); Minnesota ex rel. Pearson v. Probate Court, 309 U.S. 270 (1940); O'Connor v. Donaldson, 422 U.S. 563 (1975); Olmstead v. Georgia Department of Human Resources, 527 U.S. 581 (1999); Parham v. J.R., 442 U.S. 584 (1979); Pennhurst State School and Hospital v. Halderman, 451 U.S. 1 (1981); Secretary of Public Welfare of Pennsylvania et al., v. Institutionalized Juveniles et al., 442 US 640 (1979); Teofilo Medina, Jr. v. California, 505 U.S. 437 (1992); Terry Foucha v. Louisiana, 504 U.S. 71 (1992) te Vitek v. Jones, 445 U.S. 480 (1980).

54. Weller, P.: Reconsidering legal capacity: radical critiques, governmentality and dividing practice, Griffith Law Review, vol. 23, br. 3, str. 498.-518.

55. World Health Organisation, Calouste Gulbenkian Foundation: Improving Access to and Appropriate Use of Medicines for Mental Disorders, Ženeva, 2017.

56. Zakon o izborima zastupnika u Hrvatski sabor, NN 116/1999., 109/2000., 53/2003., 167/2003., 44/2006., 19/2007., 20/2009., 145/2010., 24/2011. i 93/2011., 19/2015.

57. Zakon o zaštiti osoba s duševnim smetnjama, NN 111/1997., 27/1998, 128/1999, 79/2002.

58. Zakon o zaštiti osoba s duševnim smetnjama, NN 76/2014.

59. Zenoff, K. E. i Norberg, C.: Reflections on Judging in a Mental Health Court and Challenges Beyond the Courtroom Doors, Southern Illinois University Law Journal, vol. 40., 2015.-2016., str. 445.-455. 


\title{
Dalida Rittossa*
}

\author{
Summary
}

\section{CONSTITUTIONAL LEGAL PROTECTION OF RIGHTS OF PEOPLE WITH MENTAL DIFFICULTIES}

In the last couple of years we have been witnessing numerous public and professional discussions of rights of people with mental difficulties and their position within the society. It is most likely that the fact that the Law on Protection of People with Mental Difficulties entered into force on $1^{\text {st }}$ of January, 2015, has, among others, instigated interesting dialogues. Legislative actions resulted in enforcement of rights and recognition of a separate status of psychiatric patients on legislative level, nevertheless, the question remains whether the rights and freedoms of this particular category of citizens are in fact recognized in practice. Bearing in mind that the constitutional legal protection is the highest possible protection of rights and freedoms of all citizens, the Constitutional Court of the Republic of Croatia entire case law has been analysed covering the period of 1992 to $1^{\text {st }}$ of November, 2017. The sample of 31 judgments and decisions analysing the constitutionality of restrictions of recognised rights of persons with mental difficulties has been individualised. A detailed analysis of the sample has revealed the constitutional standards to protect rights of persons with mental issues. The standards were compared with already established constitutional legal solutions in the European Court for Human Rights and the US Supreme Court case law. The final remarks reveal suggestions for improvement of the constitutional legal protection of persons with mental difficulties in the Republic of Croatia in the context of judicial activism.

Keywords: people with mental difficulties, constitutional legal protection of rights and freedoms of psychiatric patients, Constitutional Court of the Republic of Croatia, judicial activism.

* Dalida Rittossa, Ph. D., Assistant Professor, Faculty of Law, University of Rijeka; dalida@ pravri.hr 
Zussamenfassung

\section{VERFASSUNGSRECHTLICHER SCHUTZ DER PERSONEN MIT SEELISCHEN STÖRUNGEN}

In den letzten Jahren wurde sehr oft sowohl in der professionellen als auch in der breiten Öffentlichkeit über die Rechte und die Stellung von Personen mit seelischen Störungen diskutiert. Eines der Gründe dafür ist bestimmt das Inkrafttreten des neuen Gesetzes über die Personen mit seelischen Störungen anfangs 2015. Das Gesetz befestigte die Rechte und die besondere Stellung psychiatrischer Patienten, aber die Frage, ob die Rechte und Freiheiten dieser besonderen Bürgerkategorie auch in Praxis anerkannt werden, blieb offen. Da der verfassungsrechtliche Schutz den höchsten Schutz der Rechte und Freiheiten aller Bürger darstellt, wurde die gesamte Rechtsprechung des Verfassungsgerichts der Republik Kroatien im Zeitraum von 1992 bis zum 1. November 2017 erforscht. Es wurden 21 Entscheidungen und Beschlüsse gesammelt, in denen das Gericht über die Verfassungsmäßigkeit der Einschränkung gewährleisteter Rechte von Personen mit seelischen Störungen verhandelte. Aus der detaillierten Analyse dieser Entscheidungen und Beschlüssen wurden verfassungsrechtliche Standards über den Schutz der Rechte von Bürgern mit seelischen Störungen herausgesucht und mit den schon seit langem angenommenen verfassungsrechtlichen Beschlüssen des Europäischen Gerichtshofs für Menschenrechte und des Obersten Gerichtshofs der USA verglichen. Abschließend werden in der Arbeit Richtlinien für einen besseren verfassungsrechtlichen Schutz der Personen mit seelischen Störungen in der Republik Kroatien im Kontext der Förderung des justiziellen Aktivismus vorgeschlagen.

Schlüsselwörter: Personen mit seelischen Störungen, verfassungsrechtlicher Schutz der Rechte und Freiheiten psychiatrischer Patienten, Verfassungsgericht der Republik Kroatien, justizieller Aktivismus. 
Riassunto

\section{LA TUTELA COSTITUZIONALE DELLE PERSONE CON DISTURBI MENTALI}

Negli ultimi anni nell'ambito professionale e sociale si assiste a frequenti dibatti mediante i quali si pongono in evidenza i diritti e la posizione delle persone con disturbi mentali. Una delle ragioni che ha condotto ad interessanti diatribe è senza dubbio l'entrata in vigore della nuova Legge di protezione delle persone con disturbi mentali del 2015. Gli sforzi legislativi hanno portato ad un rafforzamento dei diritti e della specifica posizione dei pazienti psichiatrici sul piano normativo. Tuttavia rimane aperta la questione se si riconoscano realmente i diritti e le libertà di tale particolare categoria di cittadini anche nella prassi. Posto che la tutela costituzionale costituisce la protezione per eccellenza delle libertà e dei diritti di tutti i cittadini, s'è analizzata l'intera giurisprudenza della Corte Costituzionale della Repubblica di Croazia nel periodo dal 1992 al 1 novembre 2017. Sono state raccolte 31 decisioni nelle quali la corte ha dibattuto della legittimità costituzionale della limitazione dei diritti riconosciuti alle persone con disturbi mentali. Attraverso un dettagliato esame di tale campione sono stati individuati gli standard costituzionali relativi alla protezione dei diritti dei cittadini con disturbi psichici e sono stati poi comparati con le soluzioni giuridiche da tempo adottate nelle giurisprudenze della Corte europea dei diritti dell'uomo e della Corte Suprema degli Stati Uniti. Nelle riflessioni finali si suggeriscono le direttive volte a migliorare la tutela costituzionale delle persone con disturbi mentali nella Repubblica di Croazia nel contesto dello stimolo all'attivismo giudiziario.

Parole chiave: persone con disturbi mentali, protezione costituzionale delle libertà e dei diritti dei pazienti psichiatrici, Corte Costituzionale della Repubblica di Croazia, attivismo giudiziario. 
